\title{
Developing Cost Functions for Estimating Solar Photovoltaic System Installed and Life Cycle Costs Using Historical Quote Data
}

\author{
David Webb \\ Joshua Kneifel \\ Cheyney O'Fallon
}

This publication is available free of charge from: https://doi.org/10.6028/NIST.TN.2113 


\title{
Developing Cost Functions for Estimating Solar Photovoltaic System Installed and Life Cycle Costs Using Historical Quote Data
}

\author{
David Webb \\ Joshua Kneifel \\ Cheyney O'Fallon \\ Applied Economics Office \\ Engineering Laboratory
}

This publication is available free of charge from:

https://doi.org/10.6028/NIST.TN.2113

September 2020

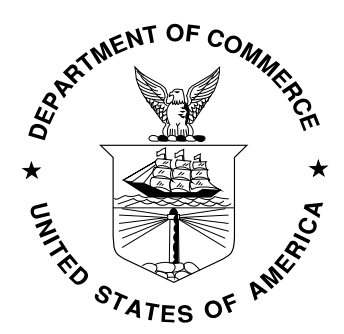

U.S. Department of Commerce

Wilbur L. Ross, Jr., Secretary

National Institute of Standards and Technology

Walter Copan, NIST Director and Undersecretary of Commerce for Standards and Technology 
Certain commercial entities, equipment, or materials may be identified in this document in order to describe an experimental procedure or concept adequately. Such identification is not intended to imply recommendation or endorsement by the National Institute of Standards and Technology, nor is it intended to imply that the entities, materials, or equipment are necessarily the best available for the purpose.

National Institute of Standards and Technology Technical Note 2113 Natl. Inst. Stand. Technol. Tech. Note 2113, 35 pages (September 2020) CODEN: NTNOEF

This publication is available free of charge from: https://doi.org/10.6028/NIST.TN.2113 


\begin{abstract}
Residential solar photovoltaic (PV) system installations have become more prevalent as the installed cost has decreased over the last 10 years while system performance has improved. As these installations have increased, so too has interest in determining their economic value to a homeowner. PV installation cost estimates have typically assumed the entire cost as marginal (average cost per watt) using reported data aggregated to a state or country. This study implements a cost function that includes a fixed cost and marginal cost element to account for differences in cost structures while controlling for panel quality and specific location. The analysis uses county level installed quote data applied to estimate cost functions and apply these functions to life cycle cost analyses of the Washington DCMaryland-Virginia (DMV) metropolitan area while incorporating state and county level differences in pricing and incentives. The estimated cost function is found to provide an installed cost estimate that is statistically different than using the traditional total average cost per watt approach for both standard and premium systems up to $9 \mathrm{~kW}$ and $11 \mathrm{kWh}$, respectively. The analysis finds no statistical difference in the installed cost function across counties, but clear differences in the life-cycle cost-effectiveness to a homeowner due to state policies and retail electricity prices. Absent financing, only PV systems in DC are life-cycle cost effective compared to retail electricity due to DC's strong solar renewable energy credit (SREC) market. PV can be cost effective in Maryland if financing and incentives are applied while no combination of financing or incentives makes PV cost effective in Virginia due to its lower relative electricity prices. Sensitivity analysis finds that the homeowner's assumed discount rate and the upcoming phase out of the federal investment tax credit (ITC) has a significant impact on residential PV economics.
\end{abstract}

\title{
Key words
}

Solar Photovoltaics; Life Cycle Cost Analysis; Net Present Value; Statistical Analysis, Solar Markets. 


\section{Table of Contents}

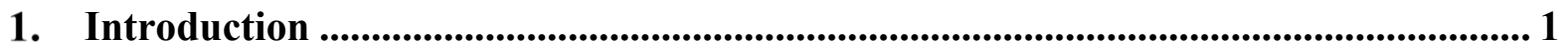

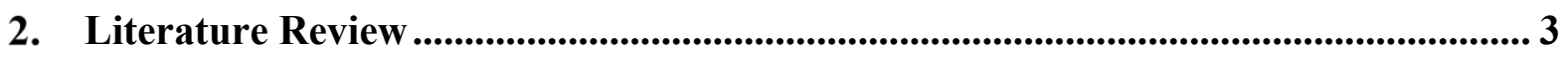

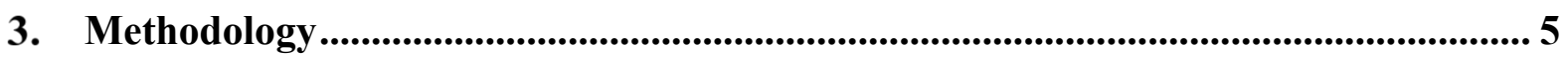

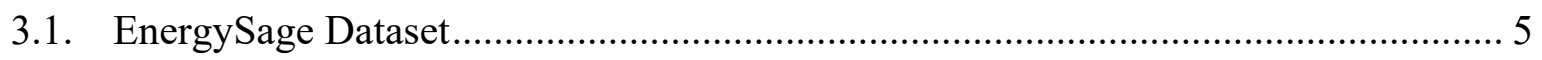

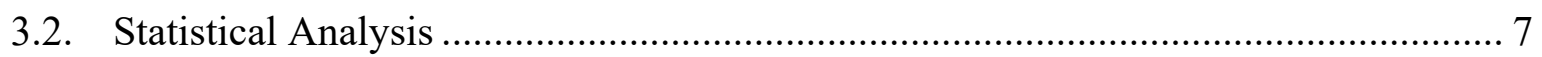

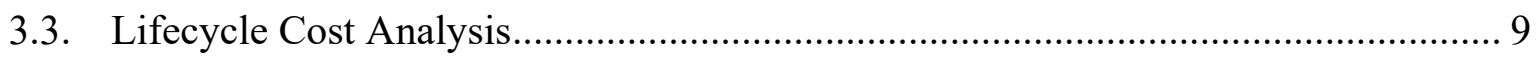

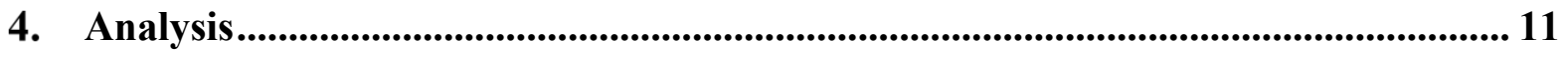

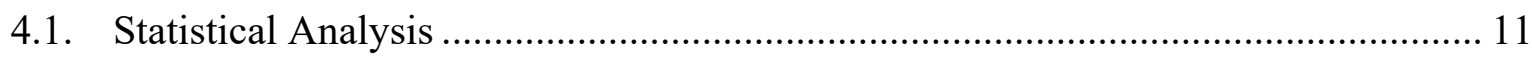

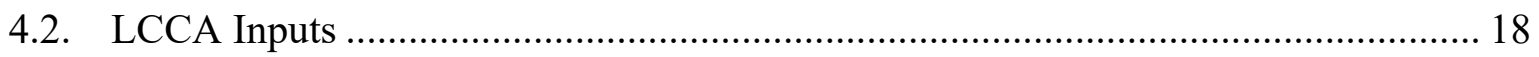

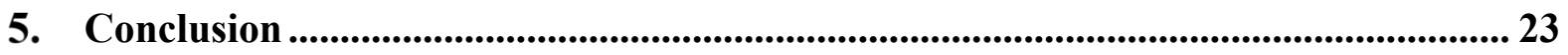

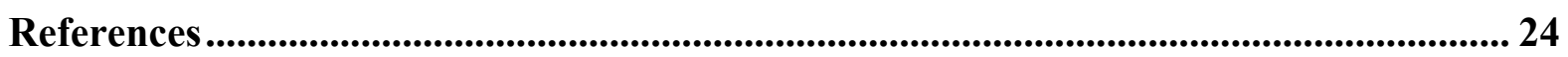

Appendix A: Supplemental Materials........................................................................................ 28

\section{List of Tables}

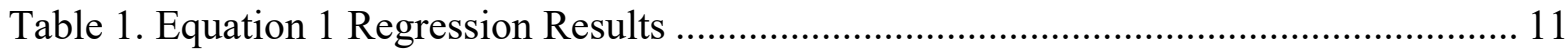

Table 2. Statistical Moments of marginal cost by year........................................................... 12

Table 3. Results of Equation 2 Regression with DC as the Base County.............................. 13

Table 4. Results of Equation 3 Regression (Standard as Base Rating) ................................. 14

Table 5. Results of Equation 4 Regression (DC as base County)........................................... 15

Table 6. Inputs for LCCA shared by all Counties ............................................................. 18

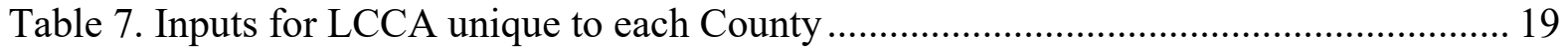

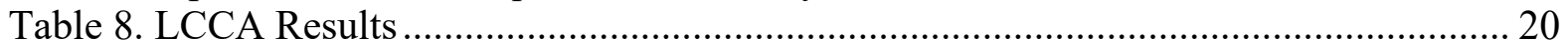

Table 9. Reductions in LCC from Incentives ................................................................ 20

Table 10. Impact of reductions on Total LCC. Shaded entries are reductions in LCC relative

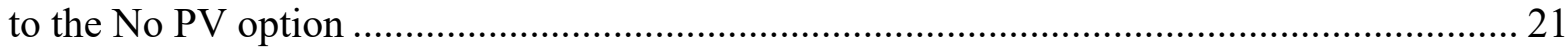

Table 11. Effects of Financing on PV LCC. Shaded entries are reductions in LCC relative to

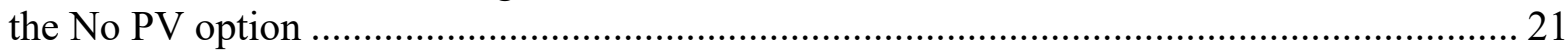
Table 12. LCCA results using a $6.5 \%$ discount rate. Shaded entries are reductions in LCC

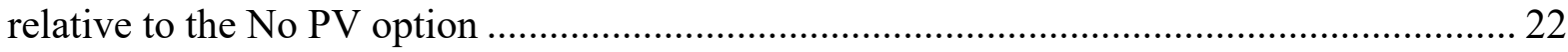
Table 13. Sensitivity of LCCA results to changes in the ITC. Shaded entries are reductions in

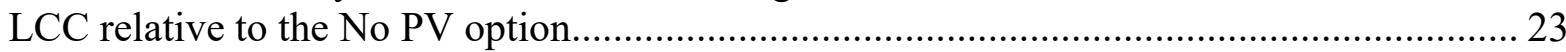

Table A-1. Results of Iterating Base Year for Regression 1 ............................................... 28

Table A-2. Results of Iterating Base Year for Regression 2 ….............................................. 28

Table A-3. Inputs for System Advisor Model ..................................................................... 29

\section{List of Figures}

Figure 1. Installed Cost versus Quoted Cost (2-Year Lag) versus Modeled (4-year Lag) ....... 2

Figure 2. Heat map of number of quotes by ZIP code .............................................................. 6 
Figure 3. Relationship between System Size and System Cost displaying Heteroskedasticity 8

Figure 4. Plot of cost functions .......................................................................................... 16

Figure 5. Plot of cost functions by Quality .................................................................. 18 


\section{Introduction}

Solar photovoltaic system installations (PV) for residential homes have expanded significantly since 2010. Analysis from the National Renewable Energy Laboratory (NREL) finds that total installations per year in the United States increased from less than 50000 in 2010 to over 350000 in 2016 [1]. The data indicates a dip in 2017, but still over 300000 new systems were installed. Given the increasing prevalence of PV, economic analysis (both current and projections) of PV systems is becoming increasingly important to understand the nature of the market.

A key driver of the growing deployment of residential PV systems has been the decrease in the installed cost to a homeowner. The reported national average installed cost of residential PV systems has decreased from nearly $\$ 10 / \mathrm{W}$ in 2008 to $\$ 3.70 / \mathrm{W}$ in 2017 [1]. The average cost has decreased due to reductions in costs for all cost categories (PV panels, inverters, balance of systems (BoS), and "soft costs" such as customer acquisition and margins) as well as economies of scale from larger median array installations (grown from $\sim 4.2 \mathrm{~kW}$ DC in 2008 to $6.3 \mathrm{~kW}_{\mathrm{DC}}$ in 2017) and improved technology such as higher median efficiency panels (grown from $14 \%$ in 2008 to 17\% in 2017). The downward trend in prices and increasing size of residential PV arrays appears to have continued in 2018 and 2019 as the quoted average installed costs of $\$ 3.05 / \mathrm{W}$ with average system size of $9.6 \mathrm{~kW}$ in the second half of 2018 and a further reduction in cost in 2019 thus far at $\$ 2.98 / \mathrm{W}$ [2].

The quoted prices have been consistently lower than the reported realized installed costs by $\$ 0.36 / \mathrm{W}$ to $\$ 0.54 / \mathrm{W}$ (9\% to $14 \%$ ), which could be driven by numerous factors. We will highlight two here. First, the two prices may be capturing different types of customers and markets. Second, the quoted prices represent potential future system installations that may not be reported for one or two years. When comparing the reported median installed costs to the average quoted cost, the quoted estimates appear to be a relatively good projection for future reported installation costs using a 2-year lag as shown in Figure 1.

Based on technical modeling, NREL has estimated the engineering-based benchmark (technically feasible) price to be $\$ 2.70 / \mathrm{W}$ [3]. The modeled benchmark installed costs has been consistently below the reported installed cost $(\$ 0.73 / \mathrm{W}$ to $\$ 0.98 / \mathrm{W})$ since 2013 . Their benchmark cost has been decreasing at a slower rate year-over-year $(\$ 0.14 / \mathrm{W}$ in 2018$)$ as the installed prices get closer to the technically feasible cost estimates. Assuming a 4-year lag on the benchmark to align it with the installed and quoted costs can be used for a projection of future average installed costs (Figure 1). 


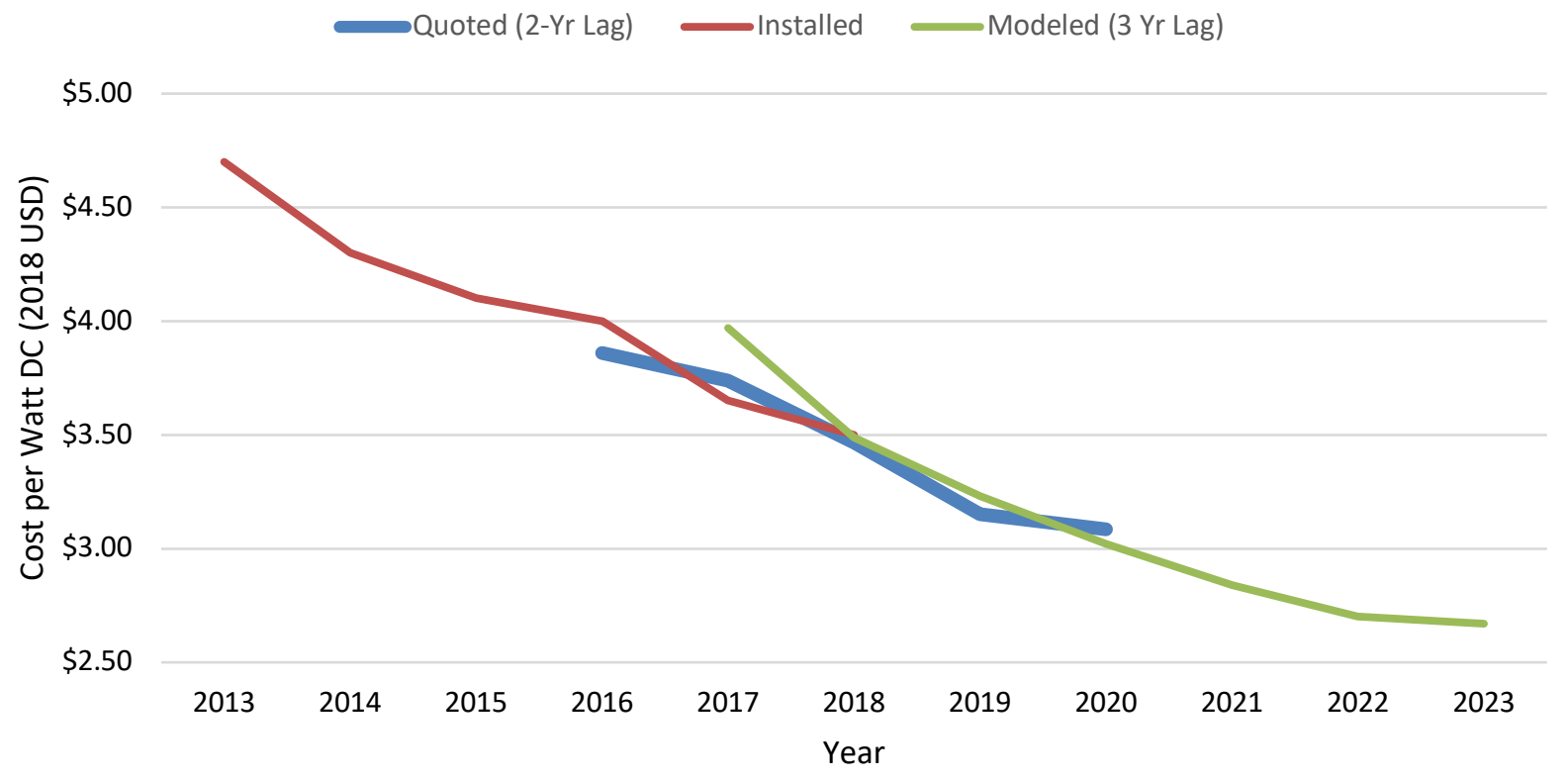

Figure 1. Installed Cost versus Quoted Cost (2-Year Lag) versus Modeled (4-year Lag)

Although this national trend is important, the decision to install a PV system is specific factors related to a homeowner's location. Barbose, Darghouth, LaCommare, Millstein and Rand (1) shows that the average installed cost across 19 states in 2017 ranges from $\$ 2.60 / \mathrm{W}$ to $\$ 4.50 / \mathrm{W}$. Similarly, EnergySage (4) shows the average quoted price for 12 states ranging from $\$ 2.72 / \mathrm{W}$ to $\$ 3.43 / \mathrm{W}$ in the second half of 2018 . There is a potential for even greater market variation across administrative and jurisdictional lines (county, city, or neighborhood level). These differences are a result of numerous factors, including customer demand/awareness, market development stage, state and local labor rules, laws, and regulations, and other regional effects.

To date, cost data has typically been reported on an average cost per watt basis. This approach makes sense when most of the costs are associated with each installed watt (solar panels and inverters). However, as these costs have become a smaller, there is potential for costs not directly associated with the size of the system (fixed costs, costs associated with the complexity of the system, differences in system quality) to account for a greater share of overall costs. For example, the median reported installed price for a system with $16 \%$ to $18 \%$ efficiency panels is $\$ 3.60 / \mathrm{W}$ versus $\$ 4.20 / \mathrm{W}$ for $20 \%$ to $21 \%$ efficiency panels [1]. Fixed costs (e.g. customer acquisition costs, permitting and commissioning) may vary based on the state or county system approval processes and the awareness of customers. Markets that are well developed with multiple installers realize lower margins, and therefore lower installed costs to homeowners [5].

This study uses a unique dataset of PV installer quotes provided to homeowners through the EnergySage platform to consider location-specific pricing (county level) for the Washington, DC metro area (DC-Maryland-Virginia or DMV), which includes Washington, DC and the four surrounding counties: Montgomery County and Prince George's County in Maryland, and Arlington County and Fairfax County in Virginia. By using quoted cost estimates, it provides a more up-to-date or even forward-looking economic analysis. This study is based 
on a case study using the National Institute of Standards and Technology (NIST) Net-Zero Residential Test Facility (NZERTF), which was constructed to study the impact of different technologies on the performance of a "typical" residential structure in Gaithersburg, Maryland in Montgomery County. While the house is limited to its physical location, the data from the NZERTF has been used to examine other physical locations by incorporating data from other similar climates [6].

The study uses an ordinary least squares regression model to: determine if there are significant differences in the "county"-level markets (including Washington DC); create a non-linear cost (but linear in parameters) model to account for higher-order or interaction terms for each unique market; and compare to the typical linear cost estimate approach. These cost models will then be used to evaluate whether each unique market has a significant trend over time in the quoted installed costs. This analysis is coupled with a lifecycle cost analysis (LCCA) utilizing the results of the county market analysis to determine the economic feasibility of a system located in each county.

\section{Literature Review}

Several organizations provide installed cost data for residential PV systems, most notably the Lawrence Berkeley National Laboratory (LBL), the National Renewable Energy Laboratory (NREL), and EnergySage. NREL provides the annual Tracking the Sun report [1] and have published numerous reports and journal articles evaluating PV market structure (O'Shaughnessy (7), O'Shaughnessy (8)). NREL reports contain trends analysis in technology installation including recent historical data ( 1 to 2 years old) and modeled engineering-based (technically feasible) cost estimates. EnergySage provides bi-annual summaries of installer quotes provided in its online customer platform. The key specifics of the included data are found in the Methodology section, but they include varying technology options, locations of the system, the size of the system, among various other energy, engineering, location, and financial information. Quotes are more representative of current and near-term future installed costs because they are estimates for systems not yet installed. Using this data provides a reasonable expected installed cost for the next year, providing current or forward-looking analysis as opposed to backward looking (historical).

These resources are insightful into the general trends of the installed cost of residential markets for PV in the United States but are generalized over large markets in most cases and focus only on installation costs. The monetary benefits of PV are dispersed over the life of the system and some costs do not accrue immediately (maintenance, replacement, grid access fees and tariffs). Economic analysis can properly account for these future costs and many prior studies have evaluated the net present value (NPV) and internal rate of return (IRR) of residential PV.

An older case study in Denmark found that investments in energy efficiency were more effective than in renewable technologies [9]. PV with a heat pump was cost-optimal for a Net-Zero structure in a dense city area while PV with district heating is the highest LCC due to high operation and maintenance costs. In terms of energy efficiency, the best performing system was a PV system coupled with a solar thermal system and solar heat pump, although it was not optimal in terms of LCC. Another study in Canada found that PV could not achieve payback in 60 years unless the initial price of electricity increased by greater than 5 
$\%$ per year using a $4 \%$ discount rate [10]. This increases to 78 years with a higher discount rate equal to the inflation rate. A study with a focus on Singapore reached similar conclusions, finding residential PV to have a higher LCC than utilizing grid-based electricity [11].

More recent studies have found PV to be more economically viable. Swift (12) examined the economics of PV by looking at locations across the United States, including specific incentives, electricity rates, and solar insolation. The IRR ranged from $31.6 \%$ in Honolulu to $8.3 \%$ in Minneapolis. By varying the installed cost of PV, the authors also estimated the required installed cost to make PV economically attractive based on IRR. Parity with grid produced electricity with and without incentives was found to be location specific. A study published in 2015 found that PV was an attractive investment in many countries even in the absence of incentives [13], once again showing highly location specific variability. FariasRocha, Hassan, Malimata, Sánchez-Cubedo and Rojas-Solórzano (14) examined the economic feasibility of PV in the Philippines by focusing on the minimum feed-in tariff, the viability of net metering, and any additional support mechanisms that would be useful for supporting PV. The authors found that a $100 \mathrm{~kW}$ feed-in tariff would be profitable for a solar investor if the tariff does not drop below 4.20 PHP/kWh. A $1.89 \mathrm{~kW}$ system was found to be financially attractive using net metering alone. A recent Canadian study examining urban deployment of rooftop PV found $96 \%$ of identified suitable rooftops would be profitable using NPV [15]. Recent studies in India have found PV to be financially viable for residential systems [16] and rural areas [17] while a study in Spain found utilizing grid electricity and natural gas for heating to be more economical than PV coupled with solar thermal and a micro-CHP system [18]. A more recent study for the United States by Lee, Hong, Koo and Kim (19) found that, depending on state and incentive, the payback period for select states in the United States ranges from as high as 25 years (Nevada and Wisconsin) to as few as 5 years (Hawaii). Maryland and Washington DC, which are most relevant to this study, had payback periods of 18 and 10 years, respectively. These differing results indicate both the improving economics of residential PV systems and the impact of regional differences when examining the LCC of PV systems.

Several studies also examine the impact of various incentives on the economics of PV. A study for the European Union examined the impact of various incentives, such as feed-in tariffs, net metering, capital subsidies, grants and rebates, and green tags [20]. The study examined multiple countries for both wind and PV, finding that depending on what incentives were available and how they were implemented, incentives can vary from beneficial to inconvenient for renewable energy sources. A partial rework by the authors expanded the number of countries considered and focused solely on feed-in tariffs finding the same basic results [21]. This finding is echoed in Dusonchet and Telaretti (22). Sow, Mehrtash, Rousse and Haillot (23) found that, for Canada, incentives allowed projects to remain feasible (based on 2016 data) with the only exception being projects in Montreal.

United States based studies also include the examination of Solar Renewable Energy Credits (SRECs). Burns and Kang (24) examined the early state of many SREC markets, finding them to be potentially strong, though the uncertainty associated with them proved to be a major drawback. Specifically, the SREC market had a higher present value than any other incentive examined (ITC, net metering, state tax credits), but the fluctuation in prices meant any benefit was highly uncertain. At the time of the study (2012) these benefits had a 
variable effect based on energy price, with less incentive required when net metering was available, while PV in Ohio was still not economically competitive due to the state's lower energy prices. An analysis examining uncertainty in the cost-effectiveness of residential PV found that incentives that reduce the uncertainty in PV returns were generally the most effective [25]. The study, focused on Massachusetts, found uncertainties that lead to delays in investment timing and the discounted benefits of PV needed to exceed investment cost by 60 $\%$ to trigger investment. A study focusing on the United States as a whole found that the impact of incentives lead to a highly variable profitability index by state [19].

This study expands the literature in four ways. First, we statistically estimate non-linear cost functions for residential PV systems using the most recent data available. Second, the DMV market is evaluated for disaggregated county level differences in the cost of solar. Third, a LCCA is completed using the cost functions while controlling for state policy variations. Finally, a sensitivity analysis is completed for two key parameters in the LCCA (discount rate and federal solar tax credit).

\section{Methodology}

\subsection{EnergySage Dataset}

The analysis uses a unique dataset provided by EnergySage (26). EnergySage aggregates quotes for solar installations from multiple PV installers provided to homeowners on its online platform for January 2013 through November 2018. Although versions of this dataset have been used before [27], this analysis is fundamentally different in that it focuses on installer pricing and firm size. Figure 2 provides a map of where quotes are located by ZIP code for the District of Columbia-Maryland-Virginia counties. Note that ZIP codes do not perfectly map to county boundaries. 


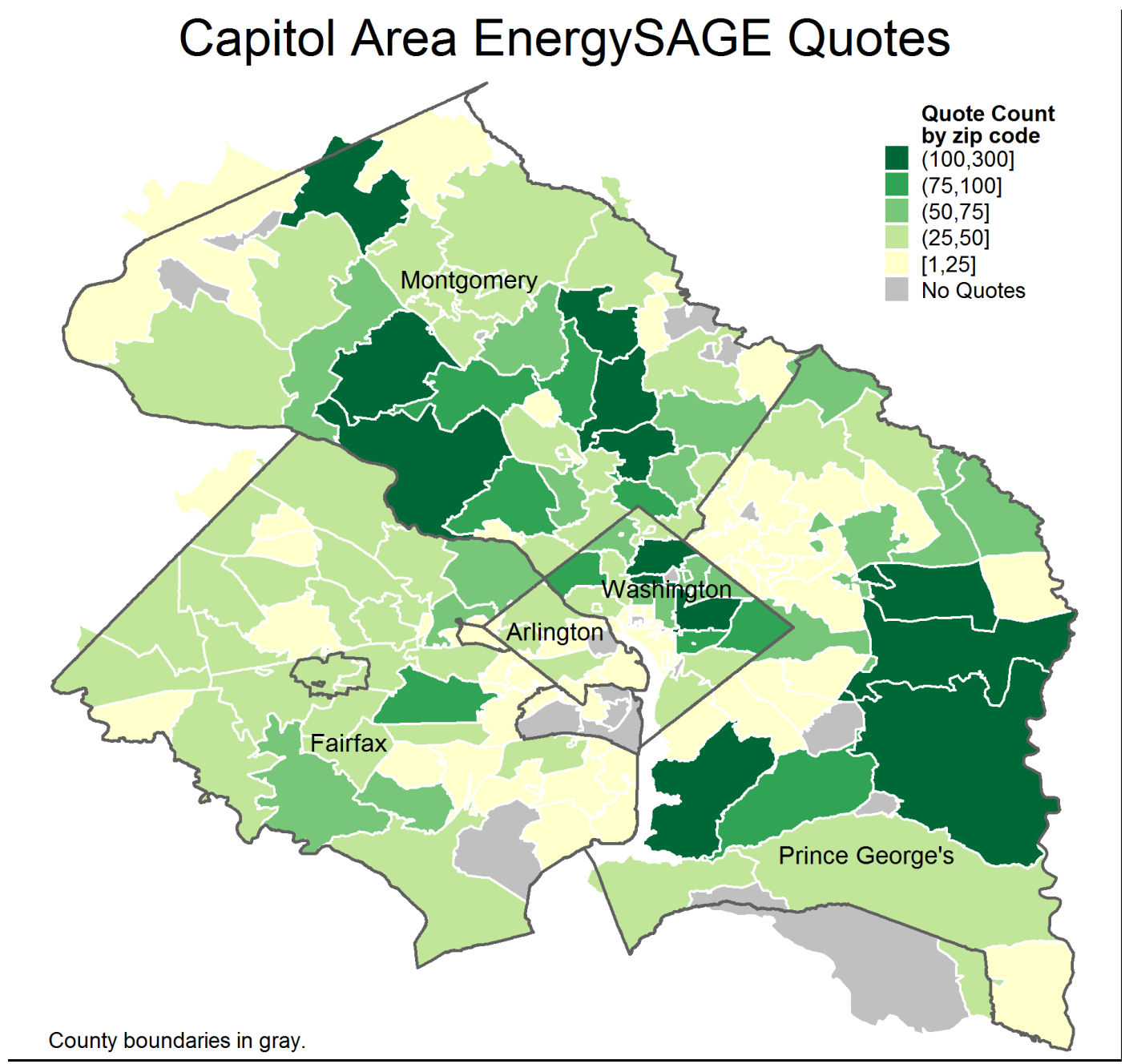

Figure 2. Heat map of number of quotes by ZIP $\operatorname{code}^{1}$

The dataset includes several variables for each quote, the most pertinent to the current analysis being:

1. Quote Date (Year)

2. System Size in Watts $($ Size $)$ - Direct Current in Watts $\left(\mathrm{W}_{\mathrm{DC}}\right)$

3. Quote for Purchase Price (Quote) in $\mathrm{USD}^{2}$

4. System Quality in Six Qualitative Tiers: economy, economy plus, standard, standard plus, premium, premium plus (Tier)

There were issues with the data due to the voluntary nature of the data input.

1. System Quality (Tier) is not consistently reported for all years and occasionally within tiers

2. Tiers do not always have a sufficient number of data points to allow analysis

3. Some quotes do not contain a quote price

${ }^{1}$ Figure made using ArcGIS

${ }^{2}$ Quotes are used because reported installed prices are not available; a quote does not always end in a purchase. 
To address the first issue a separate category for any non-tier list system is created and labeled Tier 0 . This leads to the possibility of a mixture of systems in the Tier 0 category, and therefore the Tier 0 system quotes are excluded from any analysis that includes the tier variables. The second issue is resolved by aggregating the provided tiers (non-Tier 0 labeled quotes) into a three-tier classification of economy with economy plus (labeled Economy from this point on), standard with standard plus (labeled Standard from this point on), and premium with premium plus (labeled Premium from this point on). Given the prevalence of standard and premium systems, there were not enough economy system quotes to include in the analysis, and therefore, are excluded. Issue three required dropping the no value quotes from the analysis as there was no way to determine the true value of the quoted system.

Data was provided for the District of Columbia $(D C)$ and the four surrounding counties; Arlington County, Virginia $(A C)$, Fairfax County, Virginia $(F C)$, Montgomery County, Maryland $(M C)$, and Prince George's County, Maryland $(P G)$. As a matter of simplification, any reference to "counties" as a collective, lacking further specification, includes $D C$. The analysis focuses on rooftop residential PV and excludes non-residential systems or those whose mounting system was not "penetrating rooftop" from the analysis.

Three types of inverters appear in the data set after filtering: Micro, String, and Optimizer. After filtering by all other options there were too few Micro and String inverters to get consistent statistically significant results from the analysis (AC had only 9 total observations for String inverters for 2018, while $A C$ and $F C$ had zero Standard tier Micro inverters for 2018). As such the analysis herein is limited to the Optimizer subset, which is the most commonly quoted and has an increasing market share for inverter type in the EnergySage data. Most systems quoted in 2018 have either a microinverter or optimizer. Additionally, systems with optimizers and microinverters have similar overall installed costs [1]. The historical data on installed systems supports this decision as well, with optimizers and microinverters accounting for $\sim 40 \%$ of installed systems each (over $80 \%$ total) in 2017 and the fraction of systems using optimizers increasing year-over-year at a faster rate than microinverters [1].Therefore, this restriction should be a reasonable representation of the market systems and costs. A further filter was applied to remove those systems over 50000 $\mathrm{W}_{\mathrm{DC}}^{3}$ to account for overly influential points in sparse data regions as well as erroneous data entries relative to the defined filters. After all filters were applied the sample contained 4105 data points for 2015 to $2018 .^{4}$

\subsection{Statistical Analysis}

The EnergySage dataset is analyzed using ordinary linear regression with robust standard errors to account for the heteroskedasticity apparent in Figure 3 where cost has greater variability as the system size increases. Some of the samples do not exhibit heteroskedasticity, however robust standard errors simplify to ordinary standard errors in such cases. The linear trendline for the entire EnergySage dataset shows a fixed costs (constant) of $\$ 1457$ and a variable cost of $\$ 3.02 / \mathrm{W}$.

\footnotetext{
${ }^{3}$ While states define residential cutoffs via legislation these are not used to determine the initial cutoff, as the purpose is to determine the cost function based on install, not based on legislative preference. Future work will examine how legislative cutoffs impact installer pricing.

${ }^{4} 2013$ and 2014 are omitted because there are three and zero observations, respectively.
} 


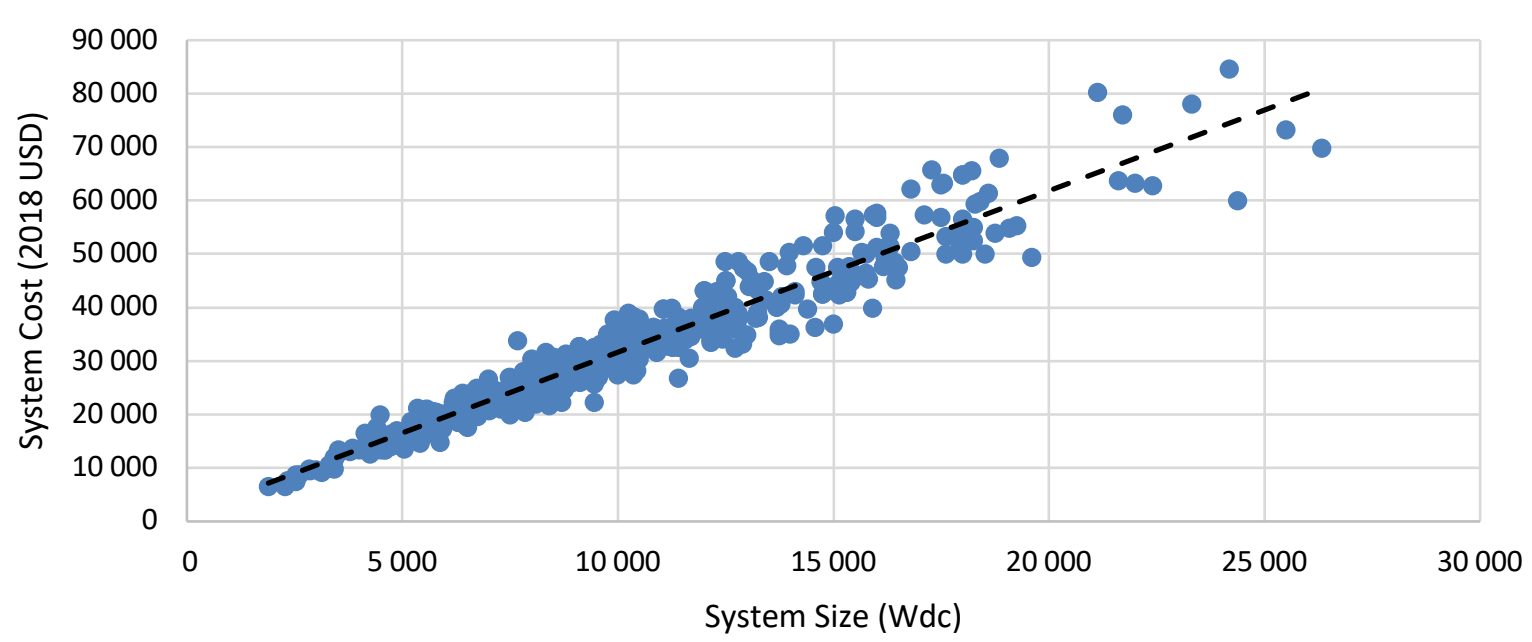

Figure 3. Relationship between System Size and System Cost displaying Heteroskedasticity

Two models are developed. The first focuses on evaluating a trend in the DMV region over time to determine if there is a statistical trend in total, fixed, and variable costs over time in hopes to allow for projecting future cost functions. The second evaluates the difference across counties and quality tiers for the most recent data (2018) to determine the locationand quality-related cost differences in current installed costs.

Interactions between variables were used to determine the significance of any difference between values. In examining the change in cost from 2015 to 2018 the regression model in Equation $1^{5}$ was developed. In this case all tiers (including Tier 0 ) are used in the regression to generate statistically significant regressions back to the initial year of the data (2015). No attempts were made to break out county or tier rating interactions because the goal of the initial regression was to look at the entire DMV region.

$$
\text { Quote }_{i}=\alpha_{1} * \text { Size }_{i}+\alpha_{2} * \text { i.year\#Size } i+\alpha_{0}+\varepsilon_{i 0}
$$

Where $\alpha_{0}$ represents the regression constant while all other $\alpha_{i}$ variables are regression coefficients for category $i$, and $\varepsilon_{i 0}$ represents an error term that is assumed to be normally distributed with a mean of zero with heteroskedasticity. The \# symbols represent interactions based on multiplying variables. i.year is an index variable for year. To determine whether all years were significantly different the i.year variable was rotated through every possible base year. Doing so allows all possible relationships between individual years to be tested for significance. These results can be found in Appendix A. The i.year variable is omitted because regressions indicated that it was not statistically significant, implying that fixed costs are not changing over time (2015 to 2018) in the DMV region. In this model $\alpha_{0}$ represents fixed costs and $\alpha_{1}$ represents marginal costs. $\alpha_{2}$ is an adjustment to the marginal cost based on the interaction term.

The regression in Equation 2 was specified to identify significant county and tier level differences. Results from this regression were also used in the subsequent LCCA and is

\footnotetext{
${ }^{5}$ i.year is omitted from this model as it was found to be insignificant (5\% level of significance) when controlling for the interaction effect. The form here is the most comparable to the current means of estimating solar PV costs.
} 
focused on the most current data. As such the regression in Equation 2 was limited to 2018 data.

$$
\begin{aligned}
& \text { Quote }_{i}=\beta_{1} * \text { Size }_{i}+\beta_{2} * i \text {. County }+\beta_{3} * i . \text { Tier }+\beta_{4} * i \text {.Tier\#Size } e_{i}+\beta_{5} \\
& * \text { i. County\#Size } e_{i}+\beta_{6} * i \text {. County\#i.Tier }+\beta_{7} \\
& * \text { i. County\#i.Tier\#Size } e_{i}+\beta_{0}+\varepsilon_{i 1}
\end{aligned}
$$

Where any variable preceded by an $i$ represents an indicator variable, $\beta_{0}$ represents the regression constant while all other $\beta_{1}$ variables are regression coefficients and $\varepsilon_{i 1}$ represents the error term, assumed normally distributed with a mean of zero but heteroskedastic. i. County and $i$.Tier are index variables for the county and tier, respectively. The reference levels for County and Tier are DC and Standard, respectively. Size is a continuous. In this model $\beta_{0}$ represents fixed costs and $\beta_{1}$ represents marginal costs while all other coefficients represent adjustments to the marginal cost due to the interaction variables. Additional regressions were run based on the results of Equation 2. The form of these regressions can be found in the Analysis section.

\subsection{Lifecycle Cost Analysis}

LCCA is a method to calculate the total cost of a purchase over time by accounting for all cash flows over the entire life of a system or investment. The LCCA uses the $\beta_{0}$ (fixed cost) and $\beta_{1}$ (variable cost) variables from each statistically viable county-tier combination as the initial installed cost per watt. Since the most recent estimates are most pertinent, only the 2018 data is used. This analysis assumes that the homeowner maintains possession of the house for the useful life of the PV system ${ }^{6}$. The analysis results may change if a different study period is selected.

The costs included in the LCCA are:

- Initial install cost

- Electricity consumption cost

- Positive if consumption is larger than generation for the year

- Negative if consumption is less than generation for the year

- Operation and Maintenance cost $(O \& M)$

- Replacement Costs for:

- Solar Panels (Optimizer panel inverters are assumed to have the same life as the panels and are replaced at the same time)

- Optimizer central inverter

- Residual Value (Linear proration of remaining value)

- Solar renewable energy credits (SRECs)

The $30 \%$ renewable energy tax credit (ITC) is included, although it will begin to be phased out in 2019.

\footnotetext{
${ }^{6}$ The assumed PV system lifetime is 25 years while the median tenure length for homeowner in a home is 13 years [28] Emrath P (2013) The "Right" Rate of Return for Energy Efficiency. (National Association of Home Builders).. Therefore, an alternative approach would be to complete the analysis for a 13-year study period and use resale value premium estimates (e.g. [29] Hoen B, Wiser R, Adomatis S, Jackson T, Graff-Zivin J, Thayer M, Klise GT (2015) SELLING INTO THE SUN: PRICE PREMIUM ANALYSIS OF A MULTI-STATE DATASET OF SOLAR HOMES. (Office of Energy Efficiency and Renewable Energy, Solar Energy Technologies Office, U.S. Department of Energy). ) as the residual value.
} 
Two methods of purchasing the system are considered, an all cash purchase and financing. It's typical for an installer to offer their own financing option or a power purchasing agreement (PPA). While the EnergySage data contains whether a financing or PPA was offered it does not provide the terms. Financing can be completed through a bank loan, allowing a generic financing option to be derived that does not require matching financing options to specific installers (or developing an average set of loan terms) in the EnergySage data. Establishing a standard $P P A$ is not feasible because they are unique to solar financing and are omitted from the analysis.

All analyses were run using an adjustment to the NZERTF PV system, which has a rated capacity of $10.2 \mathrm{~kW}$. This capacity was reduced to "right-size" the system, meaning the rated capacity is roughly equivalent to the predicted energy consumption for the first year of installation. The NZERTF system uses a string inverter, however the analysis herein will assume that an optimizer is used in the modeling to match the EnergySage data. Estimates for solar production come from the System Advisor Model (SAM) [30] and the NZERTF specifications. Energy consumption data is derived from a simulation model of the NZERTF run through EnergyPlus.

As multiple counties are considered, the rules for compensation for excess generation for each county are used as appropriate. These are tariff riders for the energy providers contract and are based on relevant state laws. Whether SRECs are available and their value are derived from the National Renewable Energy Laboratory's annual Tracking the Sun report [1] and SolSystems SREC contract options [31].

A cash flow for the full study period is generated by incorporating the individual costs for each category by year and then discounted to 2018 dollars using the equation below for net present value of a single cash flow and annual discounting where $d$ is the discount rate and $p$ is the timing of the cash flow.

$$
\text { Discounted Value }=\frac{\text { Cash Flow }}{(1+d)^{p}}
$$

The total of these discounted cash flows is summed to obtain the present value cost of the system for both purchase options (cash and loan).

Cash formula:

$$
L C C=\text { Installed Cost }+ \text { Electric Costs }+O \& M+\text { Replace Costs }-R V-I T C-S R E C
$$

Loan formula:

$$
\begin{gathered}
L C C=\text { Down Payment }+ \text { Loan Payments }+ \text { Electric Costs }+ \text { O\&M }+ \text { Replace Costs } \\
-R V-I T C-S R E C
\end{gathered}
$$

Sensitivity analysis relative to the discount rate and the ITC tax credit were performed to understand how these two parameters impact the LCCA. 


\section{Analysis}

\subsection{Statistical Analysis}

Table 1 contains the result of the Equation 1 regression with 2015 as the reference year ${ }^{7}$. The regression results for the remaining iterations through each reference year may be found in Table 14 in Appendix A.

Table 1. Equation 1 Regression Results ${ }^{8}$

\begin{tabular}{|c|c|c|c|c|c|c|}
\hline $\begin{array}{l}\text { Regression } \\
\text { Variable } \\
\text { Coefficient }\end{array}$ & Coef. & $\begin{array}{l}\text { Robust } \\
\text { Std. Err. }\end{array}$ & $\mathbf{t}$ & $P>t$ & $\begin{array}{l}\text { [95\% Con } \\
\text { Interval] }\end{array}$ & \\
\hline Size $\left(\$ / k W_{D C}\right)$ & 2.943 & .0673 & 43.74 & $<0.000$ & 2.811 & 3.075 \\
\hline \multicolumn{7}{|l|}{ Year\#Size } \\
\hline $2016\left(\$ / k_{D C}\right)$ & 0.0607 & 0.0636 & 0.95 & 0.340 & -0.0640 & 0.185 \\
\hline $2017\left(\$ / k_{D C}\right)$ & -0.339 & 0.0653 & -5.19 & $<0.000$ & -0.467 & -0.211 \\
\hline $2018\left(\$ / \mathrm{kW}_{\mathrm{DC}}\right)$ & -0.119 & 0.0623 & -1.90 & 0.057 & -0.241 & 0.00351 \\
\hline Constant (\$) & 1409 & 215.0 & 6.55 & $<0.000$ & 987.2 & 1830 \\
\hline
\end{tabular}

The results suggest that 2016 marginal costs are not statistically different than 2015, while marginal costs are statistically different for 2017 and 2018. ${ }^{9}$ Rotating the reference year produces significant differences for all marginal costs except for the 2015 and 2016 result found already (see Table 14). The trend displayed in the data is a constant marginal cost from 2015 to 2016 followed by a drop in 2017 which shows no statistically significant change in 2018. The fact that the p-value for 2018 is significant at a $10 \%$ level suggests it is worth investigating in a future model with a larger data set, especially considering that the coefficient for 2018 is larger when compared to 2017 and could be an effect of the solar tariffs implemented in 2018. However, it fails to meet the determined cutoff ( $5 \%$ level of significance) for significance here and is not discussed further.

An analysis was also run for the total average cost per watt by year for comparison purposes to the non-linear cost model (Table 2). Like the Equation 1 regression, the results in Table 2 do not account for differences in quality or county. These results show a similar trend, with 2015 and 2016 being similar, a decrease from 2016 to 2017, followed by an increase in 2018 . The primary difference is that using the total average cost per watt ${ }^{10}(\hat{X})$ assumes that the entirety of the PV system price is marginal, ignoring any fixed costs of installation. Therefore, the mean costs are consistently higher (6\% to $9 \%$ ) than the marginal cost estimates using the cost function developed in Table 1 . The focus of this paper is not on total average cost per watt (as reported in prior studies) and no difference in means hypothesis testing was completed. Thus Table 2 is meant only for a cursory comparison.

\footnotetext{
${ }^{7}$ The $\mathrm{R}^{2}$ value is 0.9829

${ }^{8} R^{2}$ is equal to 0.9387

${ }^{9}$ At a $10 \% \operatorname{LoS}$

${ }^{10}$ As based on the statistical mean in lieu of the conditional mean calculated in the regression
} 
Table 2. Statistical Moments of marginal cost by year

\begin{tabular}{|l|r|r|r|r|l|l|}
\hline Year & $\begin{array}{l}\text { Average } \\
\text { Size }\end{array}$ & $\begin{array}{l}\text { Standard } \\
\text { Deviation } \\
\text { Size }\end{array}$ & $\begin{array}{l}\text { Average } \\
\text { USD/W }\end{array}$ & $\begin{array}{l}\text { Stand. } \\
\text { Dev. } \\
\text { USD/W }\end{array}$ & $\begin{array}{l}\text { Marginal } \\
\text { Cost from } \\
\text { Regression }\end{array}$ & $\begin{array}{l}\text { Difference between } \\
\text { Average USD/W and } \\
\text { Marginal Cost from } \\
\text { Regression }\end{array}$ \\
\hline $\mathbf{2 0 1 5}$ & 7695 & 4255 & 3.21 & 0.36 & 2.94 & $0.27(9 \%)$ \\
\hline $\mathbf{2 0 1 6}$ & 9371 & 4297 & 3.18 & 0.32 & 3.00 & $0.18(6 \%)$ \\
\hline $\mathbf{2 0 1 7}$ & 9203 & 4317 & 2.75 & 0.40 & 2.60 & $0.15(6 \%)$ \\
\hline $\mathbf{2 0 1 8}$ & 10454 & 5238 & 3.02 & 0.36 & 2.82 & $0.20(7 \%)$ \\
\hline
\end{tabular}

The results of the regression in Equation 2 are provided in Table 3 (statistically significant coefficients are shaded). ${ }^{11}$ For reference there are 1108 Standard panel systems and 1026 Premium panel systems. Between counties there are 73 systems in AC, 517 systems in DC, 622 systems in FC, 639 systems in MC, and 306 systems in PG.

${ }^{11} \mathrm{R}^{2}$ value equals 0.9614 
Table 3. Results of Equation 2 Regression with DC as the Base County

\begin{tabular}{|l|r|r|r|r|r|r|}
\hline Regression Variable & \multicolumn{1}{l|}{ Coef. } & \multicolumn{1}{l|}{ Robust Std. } & \multicolumn{1}{l|}{ t } & \multicolumn{2}{l|}{ P>t } & \multicolumn{2}{l|}{ [95\% Conf. Interval] } \\
\hline County & & & & & & \\
\hline AC & 410.9 & 956.9 & 0.43 & 0.668 & -1466 & 2287 \\
\hline FC & 38.34 & 745.4 & 0.05 & 0.959 & -1423 & 1500 \\
\hline MC & -611.9 & 1163 & -0.53 & 0.599 & -2892 & 1668 \\
\hline PG & -40.10 & 817.7 & -0.05 & 0.961 & -1644 & 1564 \\
\hline Tier & 886.4 & 636.0 & 1.39 & 0.164 & -360.9 & 2134 \\
\hline Size & $\mathbf{2 . 7 8 6}$ & $\mathbf{0 . 0 6 4 0}$ & $\mathbf{4 3 . 5 7}$ & $<0.000$ & $\mathbf{2 . 6 6 1}$ & $\mathbf{2 . 9 1 2}$ \\
\hline County\#Tier & & & & & & \\
\hline AC\#Premium & 1146 & 1810 & 0.63 & 0.527 & -2403 & 4696 \\
\hline FC\#Premium & 511.0 & 1090 & 0.47 & 0.639 & -1626 & 2648 \\
\hline MC\#Premium & 285.9 & 1325 & 0.22 & 0.829 & -2313 & 2885 \\
\hline PG\#Premium & -280.8 & 1104 & -0.25 & 0.799 & -2445 & 1884 \\
\hline County\#Size & & & & & & \\
\hline AC & -0.167 & 0.117 & -1.43 & 0.154 & -0.396 & 0.0625 \\
\hline FC & -0.135 & 0.0856 & -1.58 & 0.115 & -0.303 & 0.0330 \\
\hline MC & -0.0865 & 0.131 & -0.66 & 0.51 & -0.344 & 0.171 \\
\hline PG & -0.129 & 0.0928 & -1.39 & 0.164 & -0.311 & 0.0528 \\
\hline Tier\#Size & & & & & & \\
\hline Premium & 0.122 & 0.0828 & 1.47 & 0.141 & -0.0405 & 0.284 \\
\hline County\#Tier\#Size & & & & & & \\
\hline AC\#Premium & -0.0325 & 0.188 & -0.17 & 0.862 & -0.401 & 0.336 \\
\hline FC\#Premium & 0.0310 & 0.120 & 0.26 & 0.796 & -0.204 & 0.265 \\
\hline MC\#Premium & 0.0156 & 0.150 & 0.10 & 0.917 & -0.279 & 0.310 \\
\hline PG\#Premium & 0.0682 & 0.122 & 0.56 & 0.577 & -0.172 & 0.308 \\
\hline Constant & $\mathbf{1 6 1 9}$ & $\mathbf{4 8 4 . 2}$ & $\mathbf{3 . 3 4}$ & $\mathbf{0 . 0 0 1}$ & $\mathbf{6 6 9 . 0}$ & $\mathbf{2 5 6 8}$ \\
\hline
\end{tabular}

The results in Table 3 indicate that County nor Tier have a significant impact on the regression constant. When County is interacted with Tier, no interaction has a statistical impact. County-Size interactions appear to have no significant impact as well, possibly indicating no regional differences. The only variables that have any impact are the Size variable and the regression constant. By iterating through the base county, all significant relationships between counties can be determined 12. This is unnecessary for the Tier variable since it only has two levels, so any hypothesis testing will only invert the sign of the test statistic, and under the normally distributed errors assumption will result in the same p-value. The same findings are apparent in every iteration.

While Table 3 is useful in looking at all possible combinations of the County, Tier, and Size variables, there is the possibility that it is overparametrized, confounding truly significant variables with non-significant variables. To test this concern, two less parametrized

\footnotetext{
${ }^{12}$ Regression Tables in Appendix A
} 
regressions are considered. The first removes all county interactions from the regression as in Equation 3, while the other removes Tier interactions as in Equation 4.

$$
\begin{aligned}
& \text { Quote }_{i}=\lambda_{1} * \text { Size }_{i}+\lambda_{2} * \text { i.Tier }+\lambda_{3} * \text { i.Tier\#Size } e_{i}+\lambda_{0}+\varepsilon_{i 3} \\
& \text { Quote }_{i}=\delta_{1} * \text { Size }_{i}+\delta_{2} * \text { i. County }+\delta_{3} * i \text {. County\#Size } e_{i}+\delta_{0}+\varepsilon_{i 4}
\end{aligned}
$$

Where $\lambda_{\mathrm{i}}$ and $\delta_{\mathrm{i}}$ are regression coefficients, and $\varepsilon_{\mathrm{i} 3}$ and $\varepsilon_{\mathrm{i} 4}$ are the error term for the regression, assumed heteroskedastic and normally distributed with a mean of zero. The results of these two regressions are presented in Table 4 and Table 5.

Table 4. Results of Equation 3 Regression (Standard as Base Rating) ${ }^{13}$

\begin{tabular}{|l|r|r|r|r|r|r|}
\hline $\begin{array}{l}\text { Regression } \\
\text { Variable } \\
\text { Coefficient }\end{array}$ & Value & $\begin{array}{l}\text { Robust } \\
\text { Std. Err. }\end{array}$ & t & \multicolumn{3}{|l|}{$\begin{array}{l}\text { [95\% Conf. } \\
\text { Interval] }\end{array}$} \\
\hline Tier & 1133 & 516.8 & 2.19 & 0.028 & 119.7 & 2147 \\
\hline Size & 2.670 & 0.0481 & 55.47 & $<0.000$ & 2.576 & 2.765 \\
\hline Tier\#Size & & & & & & \\
\hline \multicolumn{1}{|c|}{ Premium } & 0.157 & 0.0559 & 2.81 & 0.005 & 0.0476 & 0.267 \\
\hline Constant & 1611 & 442.4 & 3.64 & $<0.000$ & 743.1 & 2478 \\
\hline
\end{tabular}

Reducing the parameters in each regression yields a better illustration of the predominant factors impacting the installed cost. County, as evident in Table 5, has no significance at the $5 \%$ level in Equation 4, while Tier is statistically significant in Equation 3 (Table 4). Based on this we may conclude that at a $5 \% \mathrm{LoS}$, the price for a solar PV system is independent of county (limited to the counties and year examined in the data sample), but dependent on the quality of the panel ${ }^{14}$. This allows the results of Table 4 to be used across all counties, treating the five-county region as a single market ${ }^{15}$ for the purposes of the LCCA. Using the Akaike Information Criterion (AIC) and the Bayesian Information Criterion (BIC) the Tier based regression $(\mathrm{AIC}=40182, \mathrm{BIC}=40204)$ is preferable to the County based regression $(\mathrm{AIC}=40$ 552, $\mathrm{BIC}=40608)$.

\footnotetext{
${ }^{13} \mathrm{R}^{2}$ is equal to 0.9604

${ }^{14}$ Given that PG and FC both show statistically significant interactions with Size at a $10 \%$ LoS, it is possible that county level differences exist for the marginal costs. For the purposes of this study $5 \%$ was used as the cutoff. Future work should verify this result.

${ }^{15}$ A geographical analysis to check for subcounty differences was not performed and is left for future work.
} 
Table 5. Results of Equation 4 Regression (DC as base County) ${ }^{16}$

\begin{tabular}{|l|r|r|r|r|r|r|}
\hline $\begin{array}{l}\text { Regression } \\
\text { Variable } \\
\text { Coefficient }\end{array}$ & Value & $\begin{array}{l}\text { Robust } \\
\text { Std. Err. }\end{array}$ & t & \multicolumn{3}{|l|}{$\begin{array}{l}\text { P>t } \\
\text { Interval] }\end{array}$} \\
\hline County & & & & & & \\
\hline AC & 371.4 & 974.5 & 0.38 & 0.703 & -1540 & 2282 \\
\hline FC & -337.5 & 604.7 & -0.56 & 0.577 & -1523 & 848.4 \\
\hline MC & -781.7 & 594.0 & -1.32 & 0.188 & -1947 & 383.2 \\
\hline PG & -329.6 & 578.6 & -0.57 & 0.569 & -1464 & 805.0 \\
\hline Size & $\mathbf{2 . 8 9 2}$ & $\mathbf{0 . 0 3 8 6}$ & $\mathbf{7 5 . 0 3}$ & $<\mathbf{0 . 0 0 0}$ & $\mathbf{2 . 8 1 7}$ & $\mathbf{2 . 9 6 8}$ \\
\hline Size\#County & & & & & & \\
\hline AC & -0.0631 & 0.111 & -0.57 & 0.571 & -0.281 & 0.155 \\
\hline FC & -0.114 & 0.0639 & -1.78 & 0.075 & -0.239 & 0.0113 \\
\hline MC & -0.0877 & 0.0664 & -1.32 & 0.187 & -0.218 & 0.0425 \\
\hline PG & -0.107 & 0.0627 & -1.70 & 0.089 & -0.230 & 0.0162 \\
\hline Constant & $\mathbf{1 9 8 2}$ & $\mathbf{2 9 5 . 6}$ & $\mathbf{6 . 7 1}$ & $<\mathbf{0 . 0 0 0}$ & $\mathbf{1 4 0 3}$ & $\mathbf{2 5 6 2}$ \\
\hline
\end{tabular}

Plotting the two Tier regression yields Figure 5. The error bars represent the $95 \%$ confidence intervals. As would be expected, the premium systems have a slightly higher fixed (\$2744) and marginal cost $(2.827 \$ / \mathrm{W})$, resulting in a difference in price from the Standard panels (\$1611 fixed and 2.670 \$/W marginal) that increases with system size. The price based on the average quote price for 2018 is also included for comparison. The average cost in Figure 5 differs from that in Table 2 as the former includes all filters applied to the regressed data, while the latter does not. The greatest differences between the cost functions and the mean cost per watt estimate occur for smaller Premium systems and larger Standard systems. The mean cost approach leads to overestimates for Standard systems $>5 \mathrm{~kW}$ while underestimating for premium systems $<18 \mathrm{~kW}$. For the mean system size $(10454 \mathrm{~W})$, the mean cost estimate is $3.7 \%$ higher ( $\$ 1127$ with a $95 \%$ Confidence Interval (CI) of [ $\$ 717$, $\$ 1527])$ and $5.4 \%$ lower $(\$ 1651,95 \% \mathrm{CI}$ of [\$1319, \$2022]) than the cost function estimates for the Standard and Premium tiers, respectively.

${ }^{16} \mathrm{R}^{2}$ is equal to 0.9531 


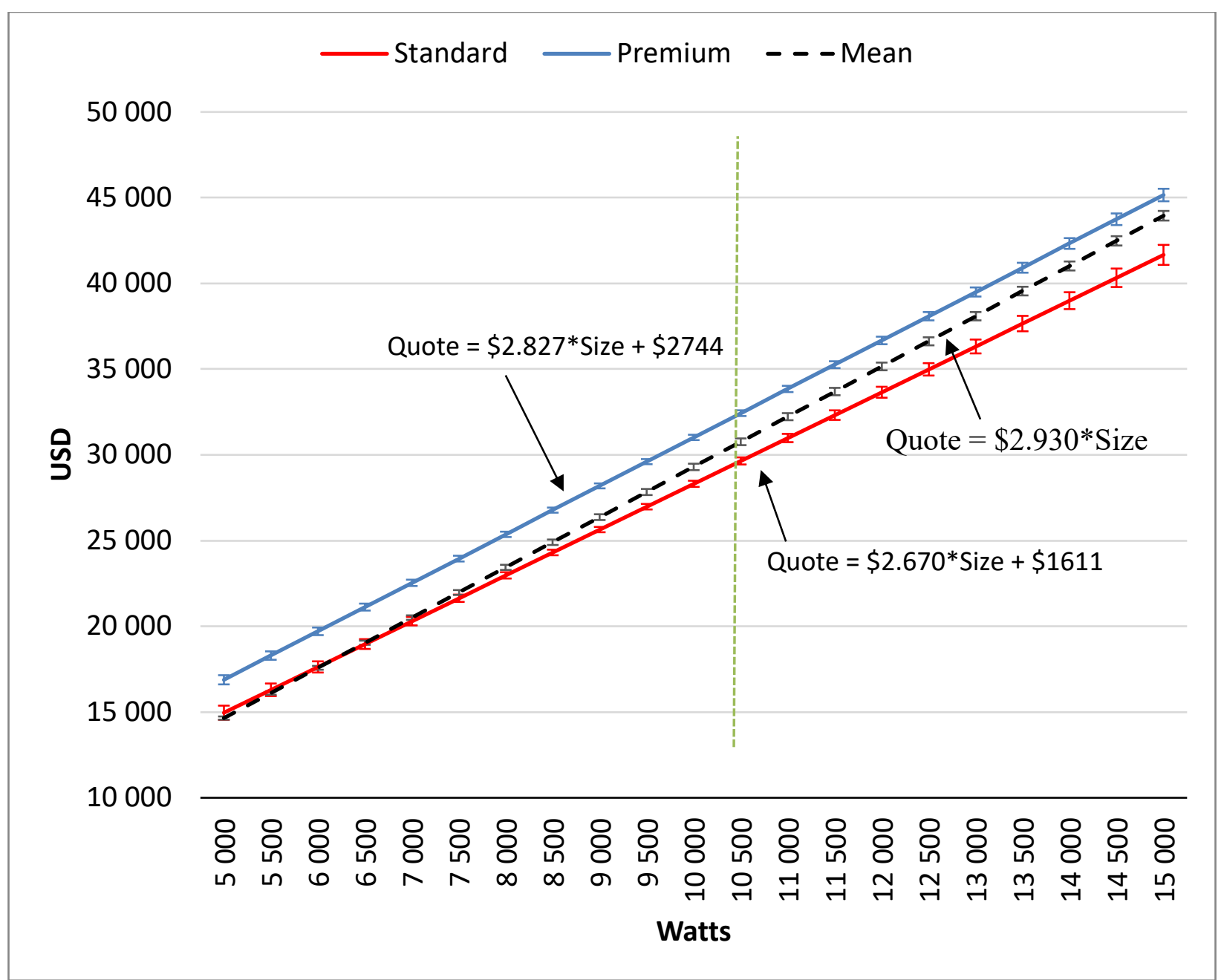

Figure 4. Plot of cost functions

This comparison does not control for system quality because most reported average cost per watt estimates are aggregated across all systems regardless of quality. Even after controlling for system quality in Figure 5, the estimated cost function is found to provide an installed cost estimate that is statistically higher $(95 \% \mathrm{CI})$ than using the traditional total average cost per watt approach for both Standard and Premium systems up to $9 \mathrm{~kW}$ and $11 \mathrm{~kW}$, respectively. The cost estimate difference decreases as capacity increases. For example, the difference for a $5 \mathrm{~kW}$ Premium system is $\$ 1739$ while the difference for the mean-sized Premium system $(10454 \mathrm{~W})$ is $\$ 625$. Note that the difference will converge to zero and then begin to increase with the cost function, leading to lower cost estimates than the average cost per watt approach at $\sim 12.4 \mathrm{~kW}$ for the Standard system and $\sim 13.8 \mathrm{~kW}$ for the Premium system. 


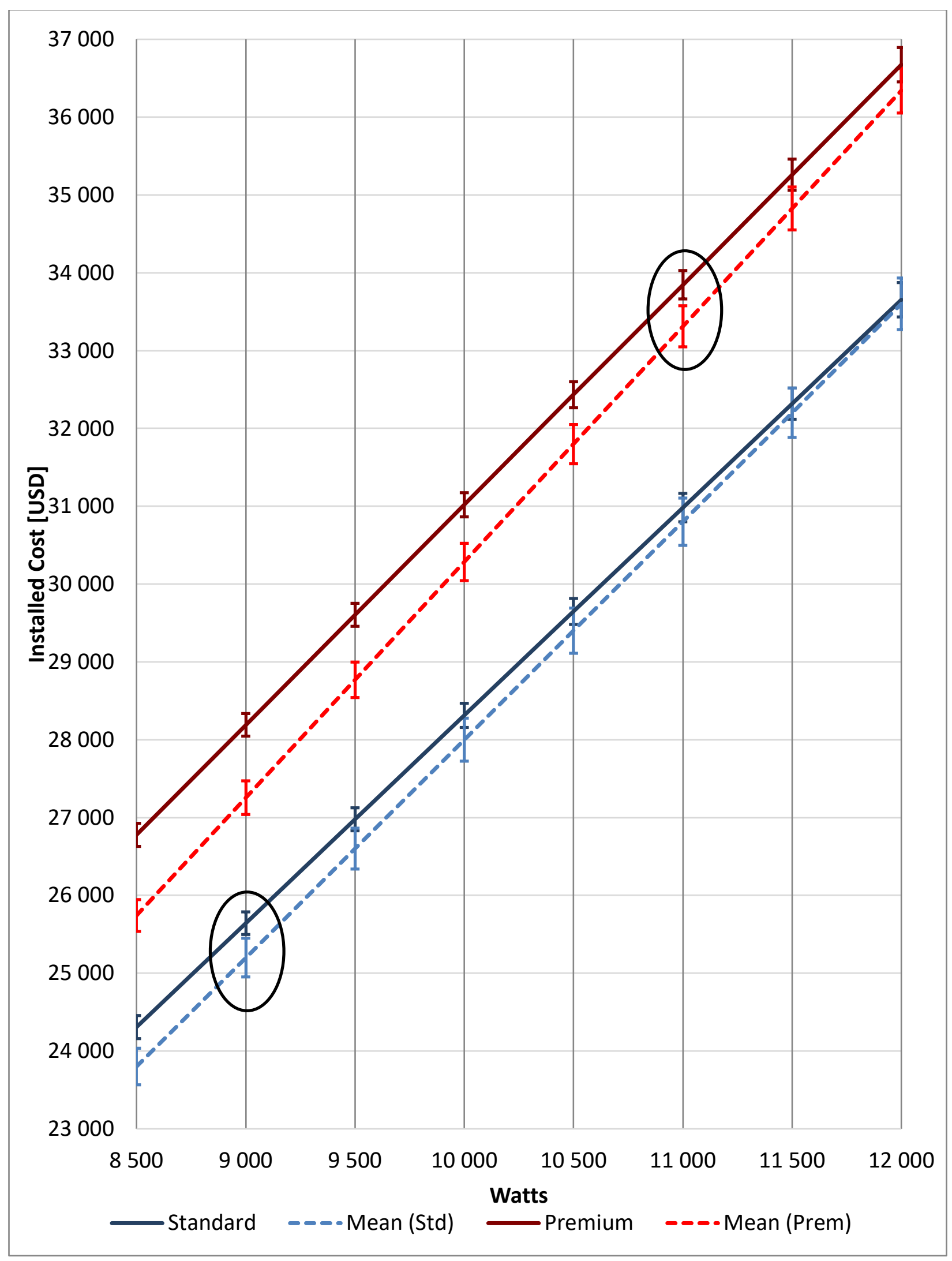


Figure 5. Plot of cost functions by Quality. Circles are meant to highlight key areas of statistical significance

\subsection{LCCA Inputs}

Table 6 contains the inputs for the LCCA shared by all counties while Table 7 contains county specific inputs. Data is collected from numerous sources, including electricity providers, government publications and software, and solar manufacturer equipment specifications.

Table 6. Inputs for LCCA shared by all Counties

\begin{tabular}{|c|c|c|}
\hline Variable & Value & Source \\
\hline System Size & $\begin{array}{l}8960 \mathrm{~W}_{\mathrm{DC}} \\
28 \text { Panels }\end{array}$ & $\begin{array}{l}\text { NZERTF Panels (SunPower SPR-E19-320) } \\
\text { adjusted to right size system. Values for } \\
\text { capacity from SAM model at reference } \\
\text { conditions. }\end{array}$ \\
\hline Inverter & $\begin{array}{l}\text {-DC Optimizer }\left(8960 \mathrm{~W}_{\mathrm{AC}}\right) \\
\text {-Cost }-0.06 \$ \mathrm{~W}_{\mathrm{AC}}\end{array}$ & $\begin{array}{l}\text {-Assumed based on EnergySage Data } \\
\text {-NREL [3] }\end{array}$ \\
\hline $\begin{array}{l}\text { PV Panel Life/Study } \\
\text { Period }\end{array}$ & 25 Years & SunPower warranty [32] \\
\hline Optimizer Life & 25 Years & From Solaris Technical Industry Inc. [33] \\
\hline Central Inverter Life & 12 Years & From Solaris Technical Industry Inc. [33] \\
\hline Maintenance Cost & $\$ 10$ per panel (28 panels) & $\begin{array}{l}\text { Upper value from HomeAdvisor [34] and } \\
\text { lower value from Renew Economy [35]. }\end{array}$ \\
\hline $\begin{array}{l}\text { Central Inverter } \\
\text { Replacement Cost }\end{array}$ & $0.18 \$ / \mathrm{W}_{\mathrm{DC}}$ & NREL [3] \\
\hline Cost & $\begin{array}{l}\text { Standard - \$25 536 } \\
\text { Premium - \$28078 }\end{array}$ & Calculated from Equation 3 Regression \\
\hline Discount Rates & $\begin{array}{l}10 \% \text { nominal rate (stated preference) } \\
1.8 \% \text { General Inflation Rate (Average } \\
\text { as of May } 2019 \text { ) }\end{array}$ & $\begin{array}{l}\text { - White Paper [28] } \\
\text { - General Inflation Rate [36] }\end{array}$ \\
\hline Weather File & $\begin{array}{l}\text { TMY3 for Dulles International } \\
\text { Airport }{ }^{17}\end{array}$ & System Advisor Model ${ }^{18}[30]$ \\
\hline Federal Tax Credit & $30 \%$ & ITC [37] \\
\hline $\begin{array}{l}\text { Loan variables } \\
\text { Down Payment } \\
\text { Nominal Interest Rate } \\
\text { General Inflation Rate } \\
\end{array}$ & $\begin{array}{l}20 \% \\
7.5 \% \\
1.8 \% \text { (Average as of May 2019) }\end{array}$ & $\begin{array}{l}\text { - Assumed } \\
\text { - Assumed } \\
\text { - General Inflation Rate [36] }\end{array}$ \\
\hline Degradation & $\begin{array}{l}1.0 \% \text { /year First five years } \\
0.4 \% / \text { year Every year after }{ }^{19}\end{array}$ & SunPower warranty [32] \\
\hline Residual Value & $\begin{array}{l}\text { Value of expected production from } \\
\text { end of study period to } 40 \text { years. } \\
\text { Valued at retail rate }\end{array}$ & 40-year life from SunPower [38] \\
\hline Escalation Rate & South Region & U.S. Department of Energy [39] \\
\hline Energy Production & $12235 \mathrm{kWh}$ & System Advisor Model Output \\
\hline Energy Consumption & $11684 \mathrm{kWh}$ & EnergyPlus Model [40] \\
\hline
\end{tabular}

\footnotetext{
${ }^{17}$ The Dulles International Airport TMY3 is used for all five counties. While doing so introduces some error in the PV generation due to the difference in latitude and solar radiation levels and errors in household consumption due to difference in weather patterns, the use of a single weather file allows for differences in regional policy and pricing to be better highlighted.

${ }^{18}$ All inputs for SAM found in Appendix A

${ }^{19}$ The SunPower warranty only extends to 25 years. The use of the $0.4 \%$ year for the residual value calculation is an author's assumption.
} 
Table 7. Inputs for LCCA unique to each County

\begin{tabular}{|c|c|c|}
\hline Variable & Value & Source \\
\hline $\begin{array}{l}\text { Energy } \\
\text { Consumption } \\
\text { Cost }\end{array}$ & $\begin{array}{l}F C-\$ 0.1104 / \mathrm{kWh} \\
A C-\$ 0.1104 / \mathrm{kWh} \\
D C-\$ 0.1282 / \mathrm{kWh} \\
M C-\$ 0.1345 / \mathrm{kWh} \\
P G-\$ 0.1342 / \mathrm{kWh}\end{array}$ & $\begin{array}{l}F C \text { - Electricity Local website [41] } \\
A C-\text { Electricity Local website [42] } \\
D C-12 \text { Month average for } 2018 \text { [43] } \\
M C-\text { Pepco bill for home in } \\
\text { Gaithersburg, MD [44] } \\
P G \text {-Southern Maryland Energy } \\
\text { Cooperative [45] }\end{array}$ \\
\hline $\begin{array}{l}\text { Net Metering } \\
\text { Policy }\end{array}$ & $\begin{array}{l}M C, P G-\text { Net Metering with excess compensated at } \\
\text { generation rate at the end of the year }(\$ 0.07300 / \mathrm{kWh} \\
\left.\text { for } M C, \$ 0.0726 / \mathrm{kWh} \text { for } P G^{20}\right) \text {. } \\
D C-\text { Net Metering with excess credits rolling over } \\
\text { month-to-month indefinitely }{ }^{21} \\
A C, F C \text { - Net Metering with credits applied to next } \\
\text { month's bill. Credits roll over up for a twelve-month } \\
\text { period. At end of twelve-month period financial } \\
\text { compensation only available through purchasing } \\
\text { agreement with utility at avoided cost rate. Otherwise } \\
\text { credits may roll over indefinitely. }\end{array}$ & $\begin{array}{l}M C-\text { Current Pepco Tariff for MD } \\
{[44]} \\
P G-\text { Southern Maryland Electric } \\
\text { Cooperative [45] } \\
D C-\text { Current Pepco Tariff for DC } \\
{[46]} \\
A C, F C-\text { Virginia Department of } \\
\text { Mines, Mineral, and Energy [47] }\end{array}$ \\
\hline $\begin{array}{l}\text { Non-Energy } \\
\text { Monthly } \\
\text { Charges }\end{array}$ & $\begin{array}{l}M C-\$ 7.959 / \mathrm{Mo} \\
P G-\$ 9.82 / \mathrm{Mo} \\
D C-\$ 15.09 / \mathrm{Mo} \\
A C-\$ 6.58 / \mathrm{Mo} \\
F C-\$ 6.58 / \mathrm{Mo}\end{array}$ & $\begin{array}{l}M C-\text { Current rates [48] } \\
P G-\text { Southern Maryland Energy } \\
\text { Cooperative [45] } \\
D C-\text { Current Pepco Tariff for DC } \\
{[46]} \\
A C / F C-\text { Current Dominion Energy } \\
\text { Tariff [49] }\end{array}$ \\
\hline SRECs $^{22}$ & $\begin{array}{l}M C / P G-\$ 50 / \mathrm{kW}_{\mathrm{DC}} \text { (estimated) for } 15 \text { years paid } \\
\text { upfront } \\
D C-\$ 1400 / \mathrm{kW}_{\mathrm{DC}} \text { (estimated) for } 15 \text { years paid } \\
\text { upfront } \\
A C / F C-\text { No established SREC market so no } \\
\text { compensation is assumed }{ }^{23}\end{array}$ & $\begin{array}{l}M C / P G-\text { From SolSystems }[50] \\
D C-\text { From SolSystems }[51] \\
A C / F C-\text { NREL }[1]\end{array}$ \\
\hline State Grant & MD - \$1000; DC - \$0; VA - \$0 & $\begin{array}{l}\text { NC Clean Energy Technology Center } \\
(52)\end{array}$ \\
\hline
\end{tabular}

Using the data from Table 6 the cost for the Standard system used in the LCCA is $\$ 25535$ with a $95 \%$ Prediction Interval (PI) of [\$19 891, \$30 392] and the Premium system has a cost of \$28 078 (PI of [ $\$ 24192, \$ 33$ 390]). Prediction intervals were estimated using quantile regression at the 0.025 and 0.975 quantiles because of the way the robust standard errors were estimated to account for heteroskedasticity. While it is possible to propagate the uncertainty due to the prediction error using simulation or other uncertainty propagation techniques such as first order Taylor series approximations, doing so while ignoring the other sources of uncertainty in the LCCA (maintenance costs, SREC valuation, energy consumption and generation, replacement times) would provide an inaccurate representation

\footnotetext{
${ }^{20} \mathrm{https}$ //Www.smeco.coop/account/residential-bill-calculator

${ }^{21}$ Roll over will occur at the end of the year for modeling purposes. The difference in this case is on the order of ones of dollars.

${ }^{22}$ While SRECS will accrue and be owned by the system owner after the upfront period ends, predicting the state of the open SREC market is infeasible, therefore any SRECs earned after the upfront period ends are not considered in the LCC.

${ }^{23}$ In the absence of renewable targets there is little pressure on utilities to purchase SRECs. While compensation is possible under Virginia net metering policies there is no open market and little data on compensation rates.
} 
of the true uncertainty for the LCCA. As such, uncertainty treatment in the LCCA is reserved for future work and all reported LCC values will be treated as deterministic.

The results of the LCCA for the No PV baseline (purchase electricity through the electric grid from a local provider) and the PV alternatives excluding incentives or financing are presented in Table 8. The Standard and Premium values include the residual value. Table 8 indicates that, absent incentives, the LCC of the No PV baseline is lower than that for the PV alternative regardless of county. This is not unexpected given the large upfront cost associated with PV installation and the discounting of future energy cost savings. Note that, PV LCCs are similar for all counties (within $\$ 1000$ for each Tier) because the LCC is largely driven by the marginal cost of installation and is therefore system size and quality dependent.

Table 8. LCCA Results

\begin{tabular}{|l|c|r|r|}
\hline County & \multicolumn{1}{|l|}{$\begin{array}{l}\text { No PV } \\
\text { LCC }\end{array}$} & Standard & Premium \\
\hline MC & $\$ 19076$ & $\$ 29027$ & $\$ 31570$ \\
\hline PG & $\$ 19274$ & $\$ 29269$ & $\$ 31812$ \\
\hline DC & $\$ 19143$ & $\$ 30000$ & $\$ 32542$ \\
\hline FC & $\$ 15664$ & $\$ 29110$ & $\$ 31652$ \\
\hline AC & $\$ 15664$ & $\$ 29110$ & $\$ 31652$ \\
\hline
\end{tabular}

Table 9 summarizes the effects of incentives on the LCCA. The federal tax credit is available to all homeowners, and therefore provides the same value in all five counties. Counties in Maryland receive a $\$ 1000$ grant incentive while DC and Virginia do not receive a grant. The SRECs in DC have a large impact (\$11 615) while minimal to no impact in the other four counties (\$0 in Virginia and \$415 in Maryland).

Table 9. Reductions in LCC from Incentives

\begin{tabular}{|l|r|r|r|r|r|r|}
\hline \multirow{2}{*}{ County } & \multicolumn{2}{l|}{$\begin{array}{l}\text { Tax Credits \& } \\
\text { Grants }\end{array}$} & \multicolumn{2}{l|}{ TRECs } & \multicolumn{2}{l|}{ Total } \\
\cline { 2 - 7 } & Standard & Premium & \multicolumn{1}{l|}{ Standard } & \multicolumn{1}{l|}{ Premium } & \multicolumn{1}{l|}{ Standard } & Premium \\
\hline MC & $\$ 8661$ & $\$ 9423$ & $\$ 415$ & $\$ 415$ & $\$ 9076$ & $\$ 9838$ \\
\hline PG & $\$ 8661$ & $\$ 9423$ & $\$ 415$ & $\$ 415$ & $\$ 9076$ & $\$ 9838$ \\
\hline DC & $\$ 7661$ & $\$ 8423$ & $\$ 11615$ & $\$ 11615$ & $\$ 19276$ & $\$ 20038$ \\
\hline FC & $\$ 7661$ & $\$ 8423$ & $\$ 0$ & $\$ 0$ & $\$ 7661$ & $\$ 8423$ \\
\hline AC & $\$ 7661$ & $\$ 8423$ & $\$ 0$ & $\$ 0$ & $\$ 7661$ & $\$ 8423$ \\
\hline
\end{tabular}

Table 10 summarizes the incentives and the impact on the LCCA. Except for DC (shaded in Table 10), the total LCC for the PV alternative is greater than the No PV baseline. This suggests that current incentives are not sufficient to overcome the high upfront cost of the PV installation given the LCC input value assumptions. $D C$ 's smaller LCC is due to the robust SREC market currently versus Virginia with no SREC market and the SREC market for Maryland ( $M C$ and $P G)$ providing minimal financial incentives. ${ }^{24}$ The Maryland counties

\footnotetext{
${ }^{24}$ With the passage Maryland SB 516 Maryland set a goal of $50 \%$ renewable energy by 2030 . This has the possibility of changing the nature of the SREC market for the state depending on how it is implemented. This work makes no predictions on what effects, if any, will result from the bill.
} 
( $M C$ and $P G$ ) are relatively close to being competitive ( $\$ \sim 900$ for Standard and $\sim \$ 2700$ for Premium, respectively) and, should a consumer find that one or more assumption in the LCCA is too conservative (e.g. discount rate), could be the best alternative for their situation. The Virginia counties $(F C$ and $A C$ ) have a lower electricity consumption price than those in DC or Maryland, making PV less LCC competitive ( $>5000$ for both PV alternatives and counties).

Table 10. Impact of reductions on Total LCC. Shaded entries are reductions in LCC relative to the No PV option

\begin{tabular}{|l|r|r|r|r|}
\hline \multirow{2}{*}{ County } & \multicolumn{2}{|l|}{ Total LCC after reduction } & \multicolumn{2}{l|}{$\Delta$ LCC from No PV LCC } \\
\cline { 2 - 5 } & \multicolumn{1}{|c|}{ Standard } & Premium & \multicolumn{1}{l|}{ Standard } & \multicolumn{1}{l|}{ Premium } \\
\hline MC & $\$ 19951$ & $\$ 21732$ & $\$ 875$ & $\$ 2656$ \\
\hline PG & $\$ 20193$ & $\$ 21974$ & $\$ 919$ & $\$ 2700$ \\
\hline DC & $\$ 10721$ & $\$ 12504$ & $-\$ 8422$ & $-\$ 6639$ \\
\hline FC & $\$ 21449$ & $\$ 23229$ & $\$ 5785$ & $\$ 7565$ \\
\hline AC & $\$ 21449$ & $\$ 23229$ & $\$ 5785$ & $\$ 7565$ \\
\hline
\end{tabular}

Table 11 examines the impact of using financing to purchase the PV system excluding (1) and including (2) incentives. Since the interest rate is lower than the assumed discount rate, financing decreases total LCC by $\$ 2495$ (or $\$ 2496$ depending on rounding) for the Standard system and \$2745 (or \$2744 depending on rounding) for the Premium system. Using financing to pay for the initial installation results in a decrease in the total LCC to the point where the Maryland counties, if other incentives are applied, are the lowest LCC compared to the No PV baseline for both Standard and Premium systems. The Virginia counties, even with financing and incentives, cannot match the LCC of the No PV baseline. Given the dependence of financing on the interest rate and discount rate, which are both going to be individual based, it is impossible to make further statements on the applicability of this result to specific prospective PV purchasers.

Table 11. Effects of Financing on PV LCC. Shaded entries are reductions in LCC relative to the No PV option

\begin{tabular}{|c|c|c|c|c|c|c|c|c|}
\hline \multirow[t]{2}{*}{ County } & \multicolumn{2}{|c|}{$\begin{array}{l}\text { Total LCC with } \\
\text { Financing (1) }\end{array}$} & \multicolumn{2}{|c|}{$\begin{array}{l}\Delta L C C(1) \text { from No PV } \\
L C C\end{array}$} & \multicolumn{2}{|c|}{$\begin{array}{l}\text { Total LCC with } \\
\text { Financing and } \\
\text { Incentives (2) }\end{array}$} & \multicolumn{2}{|c|}{$\begin{array}{l}\Delta L C C(2) \text { from No PV } \\
L C C\end{array}$} \\
\hline & Standard & Premium & Standard & Premium & Standard & Premium & Standard & Premium \\
\hline MC & $\$ 26531$ & $\$ 28826$ & $\$ 7456$ & $\$ 9750$ & $\$ 17456$ & $\$ 18987$ & $-\$ 1620$ & $-\$ 85$ \\
\hline PG & $\$ 25133$ & $\$ 29067$ & $\$ 7500$ & $\$ 9793$ & $\$ 17697$ & $\$ 19229$ & $-\$ 1575$ & $-\$ 44$ \\
\hline DC & $\$ 26844$ & $\$ 29798$ & $\$ 8361$ & $\$ 10655$ & $\$ 8228$ & $\$ 9760$ & $-\$ 10915$ & $-\$ 9384$ \\
\hline FC & $\$ 25953$ & $\$ 28908$ & $\$ 10950$ & $\$ 13244$ & $\$ 18953$ & $\$ 20484$ & $\$ 3289$ & $\$ 4820$ \\
\hline AC & $\$ 25953$ & $\$ 28908$ & $\$ 10950$ & $\$ 13244$ & $\$ 18953$ & $\$ 20484$ & $\$ 3289$ & $\$ 4820$ \\
\hline
\end{tabular}

A sensitivity analysis was performed to understand the impacts of discount rate on the LCCA. In lieu of the $10 \%$ nominal ( $~ 8 \%$ real, stated preference) rate, Siegel's constant (6.5 $\%$ to $7 \%$ in real terms, revealed preference) is used for the LCCA [53]. Siegel's constant is the long-term average annual rate of return on stocks based on 200 years of data (1794 to 1994). The lower end of this range (6.5\%) was selected. Table 12 contains these results with 
counties where PV is preferred to the No PV baseline are shaded. The lower discount rate does not change the relative performance of PV systems to the No PV baseline, but does further improve the economics of PV systems in all counties. Solar PV in $D C, M C$, and $P G$ becomes even more LCC effective at the lower discount rate while $\mathrm{PV}$ in $F C$ and $A C$ remain unable to match the No PV baseline's LCC, although coming within $\$ 2323$ and $\$ 3938$ for Standard and Premium systems, respectively. Further reductions of $\$ 0.26 / \mathrm{W}$ and $\$ 0.44 / \mathrm{W}$ in marginal installed costs could make Standard and Premium systems, respectively, costeffective in Virginia.

Table 12. LCCA results using a $6.5 \%$ discount rate. Shaded entries are reductions in LCC relative to the No PV option

\begin{tabular}{|l|l|l|l|l|l|l|l|l|l|}
\hline & \multicolumn{9}{|c|}{ LCC } \\
\hline County & \multirow{2}{*}{ No PV } & $\begin{array}{l}\text { Total w/ No } \\
\text { Incentives or } \\
\text { Financing }\end{array}$ & \multicolumn{2}{l|}{$\begin{array}{l}\text { Total After } \\
\text { Incentives }\end{array}$} & \multicolumn{2}{l|}{$\begin{array}{l}\text { Total using } \\
\text { financing }\end{array}$} & \multicolumn{2}{l|}{$\begin{array}{l}\text { Financing w/ } \\
\text { Incentives }\end{array}$} \\
\cline { 3 - 10 } & Std. & Prem. & Std. & Prem. & Std. & Prem. & Std. & Prem. \\
\hline MC & $\$ 21816$ & $\$ 28896$ & $\$ 31438$ & $\$ 19815$ & $\$ 21594$ & $\$ 27680$ & $\$ 30101$ & $\$ 18598$ & $\$ 20257$ \\
\hline PG & $\$ 22042$ & $\$ 29174$ & $\$ 31717$ & $\$ 20093$ & $\$ 21872$ & $\$ 27958$ & $\$ 30379$ & $\$ 18876$ & $\$ 20535$ \\
\hline DC & $\$ 21892$ & $\$ 30036$ & $\$ 32578$ & $\$ 10597$ & $\$ 12376$ & $\$ 28819$ & $\$ 31241$ & $\$ 9380$ & $\$ 11038$ \\
\hline FC & $\$ 17914$ & $\$ 29114$ & $\$ 31657$ & $\$ 21454$ & $\$ 23233$ & $\$ 27898$ & $\$ 30320$ & $\$ 20237$ & $\$ 21896$ \\
\hline AC & $\$ 17914$ & $\$ 29114$ & $\$ 31657$ & $\$ 21454$ & $\$ 23233$ & $\$ 27898$ & $\$ 30320$ & $\$ 20237$ & $\$ 21896$ \\
\hline
\end{tabular}

The results thus far are based on quote data from 2018, which may be a reasonable estimate for decisions in 2019 and (to a lesser extent in 2020) based on Figure 1. The analysis in this study can be used to provide some insight on the potential sensitivity of the LCCA results for the DMV area to the phase out of the federal tax credit. The exact ITC phase out schedule is: $2019-30 \%, 2020-26 \%, 2021-21 \%$, and $2022-0 \%$.

For the tax credit sensitivity analysis, the $10 \%$ nominal ( $8 \%$ real) discount rate is used. It also assumes that the cost function for 2018 produces a quote that an installer will be willing to honor for the full duration of the phase out (based on the EnergySage data 2020 is realistically the last viable year for this assumption) and that installers do not account for changes to the tax credit when quoting out systems. These assumptions are likely incorrect on their face, however predicting price trends from the current EnergySage data in a cost function form (several analyses predict price trends by treating the entire installation cost as marginal) is left for future work. Any results from the tax credit sensitivity analysis should therefore be understood to represent the sensitivity of a 2018 quote to future decreases in tax credits and not a prediction of future price trends or a predictive analysis of future PV systems. Table 13 summarizes the results of the tax credit sensitivity results.

Table 13 shows that in $D C$, with its strong SREC market, the tax credit is not required for PV to be the lowest LCC alternative regardless of whether financing is used. The Premium system in the Maryland counties required both financing and the $30 \%$ ITC to be preferred to the No PV baseline. The Standard system remains preferred at the $26 \%$ ITC but is no longer preferred when the tax credit drops to $21 \%$. No combination made PV the preferred alternative in the Virginia counties with the full tax credit applied and, therefore, there is no change in preference as it is phased out. 
Table 13. Sensitivity of LCCA results to changes in the ITC. Shaded entries are reductions in LCC relative to the No PV option

\begin{tabular}{|c|c|c|c|c|c|c|c|c|c|c|}
\hline \multirow{2}{*}{$\begin{array}{l}\text { Tax } \\
\text { Credit }\end{array}$} & \multirow[t]{2}{*}{ County } & \multirow{2}{*}{$\begin{array}{l}\text { No PV } \\
\text { LCC }\end{array}$} & \multicolumn{2}{|l|}{ PV LCC } & \multicolumn{2}{|c|}{$\begin{array}{l}\text { Total After } \\
\text { Incentives }\end{array}$} & \multicolumn{2}{|c|}{$\begin{array}{l}\text { Total using } \\
\text { financing }\end{array}$} & \multicolumn{2}{|c|}{$\begin{array}{l}\text { Financing w/ } \\
\text { Incentives }\end{array}$} \\
\hline & & & Std. & Prem. & Std. & Prem. & Std. & Prem. & Std. & Prem. \\
\hline \multirow{5}{*}{$26 \%$} & MC & $\$ 19076$ & $\$ 29027$ & $\$ 31570$ & $\$ 20973$ & $\$ 22855$ & $\$ 26532$ & $\$ 28826$ & $\$ 18477$ & $\$ 20110$ \\
\hline & PG & $\$ 19274$ & $\$ 29269$ & $\$ 31812$ & $\$ 21215$ & $\$ 23097$ & $\$ 26774$ & $\$ 29067$ & $\$ 18719$ & $\$ 20352$ \\
\hline & DC & $\$ 19143$ & $\$ 30000$ & $\$ 32542$ & $\$ 11746$ & $\$ 13627$ & $\$ 27504$ & $\$ 29798$ & $\$ 9250$ & $\$ 10883$ \\
\hline & FC & $\$ 15664$ & $\$ 29110$ & $\$ 31652$ & $\$ 22470$ & $\$ 24352$ & $\$ 26614$ & $\$ 28908$ & $\$ 19975$ & $\$ 21607$ \\
\hline & $A C$ & $\$ 15664$ & $\$ 29110$ & $\$ 31652$ & $\$ 22470$ & $\$ 24352$ & $\$ 26614$ & $\$ 28908$ & $\$ 19975$ & $\$ 21607$ \\
\hline \multirow{5}{*}{$21 \%$} & MC & $\$ 19076$ & $\$ 29027$ & $\$ 31570$ & $\$ 22250$ & $\$ 24259$ & $\$ 26532$ & $\$ 28826$ & $\$ 19754$ & $\$ 21514$ \\
\hline & PG & $\$ 19274$ & $\$ 29269$ & $\$ 31812$ & $\$ 22492$ & $\$ 24501$ & $\$ 26774$ & $\$ 29067$ & $\$ 19996$ & $\$ 21756$ \\
\hline & DC & $\$ 19143$ & $\$ 30000$ & $\$ 32542$ & $\$ 13023$ & $\$ 15031$ & $\$ 27504$ & $\$ 29798$ & $\$ 10527$ & $\$ 12287$ \\
\hline & FC & $\$ 15664$ & $\$ 29110$ & $\$ 31652$ & $\$ 23747$ & $\$ 25756$ & $\$ 26614$ & $\$ 28908$ & $\$ 21251$ & $\$ 23011$ \\
\hline & $A C$ & $\$ 15664$ & $\$ 29110$ & $\$ 31652$ & $\$ 23747$ & $\$ 25756$ & $\$ 26614$ & $\$ 28908$ & $\$ 21251$ & $\$ 23011$ \\
\hline \multirow{5}{*}{$0 \%$} & MC & $\$ 19076$ & $\$ 29027$ & $\$ 31570$ & $\$ 27613$ & $\$ 30155$ & $\$ 26532$ & $\$ 28826$ & $\$ 25117$ & $\$ 27411$ \\
\hline & PG & $\$ 19274$ & $\$ 29269$ & $\$ 31812$ & $\$ 27855$ & $\$ 30397$ & $\$ 26774$ & $\$ 29067$ & $\$ 25359$ & $\$ 27653$ \\
\hline & DC & $\$ 19143$ & $\$ 30000$ & $\$ 32542$ & $\$ 18385$ & $\$ 20928$ & $\$ 27504$ & $\$ 29798$ & $\$ 15889$ & $\$ 18183$ \\
\hline & FC & $\$ 15664$ & $\$ 29110$ & $\$ 31652$ & $\$ 29110$ & $\$ 31652$ & $\$ 26614$ & $\$ 28908$ & $\$ 26614$ & $\$ 28908$ \\
\hline & $A C$ & $\$ 15664$ & $\$ 29110$ & $\$ 31652$ & $\$ 29110$ & $\$ 31652$ & $\$ 26614$ & $\$ 28908$ & $\$ 26614$ & $\$ 28908$ \\
\hline
\end{tabular}

The difference in LCC between the PV alternative and the No PV baseline can be used to estimate the additional drop in the installed price required to make a homeowner indifferent between the two alternatives as the ITC phases out. For Maryland, the Standard system is cost effective for a $26 \%$ ITC but would require a drop in the installed cost of $\sim \$ 700$ $\left(\$ 0.08 / \mathrm{W}_{\mathrm{DC}}\right)$ and $\sim 6000\left(\$ 0.67 / \mathrm{W}_{\mathrm{DC}}\right)$ for the $21 \%$ ITC and $0 \%$ ITC, respectively. The Premium system would require a drop in the installed cost of $\sim \$ 1000\left(\$ 0.11 / \mathrm{W}_{\mathrm{DC}}\right), \sim \$ 2500$ $\left(\$ 0.28 / \mathrm{W}_{\mathrm{DC}}\right)$, and $\sim \$ 8400\left(\$ 0.94 / \mathrm{W}_{\mathrm{DC}}\right)$ for the $26 \%, 21 \%$, and $0 \%$ ITC, respectively. For Virginia, the Standard system would require a drop in the installed cost of $\$ 3300$ $\left(\$ 0.37 / \mathrm{W}_{\mathrm{DC}}\right), \$ 4300\left(\$ 0.48 / \mathrm{W}_{\mathrm{DC}}\right), \$ 5500\left(\$ 0.61 / \mathrm{W}_{\mathrm{DC}}\right)$, and $\$ 10970\left(\$ 1.23 / \mathrm{W}_{\mathrm{DC}}\right)$ for the $30 \%, 26 \%, 21 \%$, and $0 \%$ scenarios.

\section{Conclusion}

Solar PV continues to be the most popular renewable energy source available to homeowners and it is, therefore, important to understand the economics of these systems. Because a substantial portion of the economics of these systems are a result of regional markets and local and state regulations, an examination of regional impacts is important. While studies of this kind have been done using simple averages for entire states, nations, or a single structure, this study focuses on the boundary between five jurisdictions including multiple PV installers with recent quote data. Political boundaries like those in the DC-Maryland-Virginia area allow for natural experiments in how different solar PV policies impact the cost effectiveness of installed systems. The use of cost functions in lieu of simple averages allows the fixed 
costs of installation to be separated from the marginal costs, providing a better picture of how PV installation pricing works in practice.

In examining Washington DC and the four surrounding counties it's found that that solar PV pricing is largely similar for the region. A comparison of the estimated cost functions to the mean cost approach used by previous studies show the greatest differences for very small or very large systems depending on the quality tier. A difference of $\$ 1127$ (3.7\%, 95\% CI of [\$717, \$1527]) for the Standard system to $\$ 1651(5.4 \%, 95 \%$ CI of [\$1319, \$2022]) for the Premium system is found for the mean sized system (10 $454 \mathrm{~W})$. After controlling for system quality, the estimated cost function is found to provide an installed cost estimate that is statistically different than using the traditional total average cost per watt approach for both Standard and Premium systems up to $9 \mathrm{~kW}$ and $11 \mathrm{kWh}$, respectively. For upfront (cash) purchases, the LCC for the assumed PV systems remain higher for grid-based electricity for all counties except $D C$. $D C$ has a strong SREC market, which allows it to overcome the substantial first costs associated with solar PV installation. With higher electricity prices, the Maryland counties find PV to be more competitive with grid-based generation than the Virginia counties, and can achieve LCC parity if incentives are applied. Greater reductions in solar PV installation costs are required for PV to remain LCC competitive absent financing and as the ITC begins to phase out. Alternatively, if the average discount rate associated with homebuyers were lower than that used in this study, then present value of future savings and gains would be higher, possibly maintaining cost competitiveness. Incorporating financing can make the assumed PV system viable for more counties assuming all incentives are also incorporated. Whether or not a potential purchaser can afford the initial down payment, or the monthly payments is an important constraint outside the scope of this paper.

This study highlights several areas of future work. Future studies should track changes in solar PV economics, regulations, and markets to understand how the LCC of PV systems evolves. Replicating this study using a broader dataset (i.e. 2019 data and other counties in Maryland and Virginia) could lead to more statistically significant differences across counties. The creation of predictive models that use a cost function in place of simple averages could help achieve more accurate estimates and allow for the dynamics of the tax credit expiration to be evaluated more effectively. More regional analysis covering a larger geographic area (or multiple geographic areas) is also vital to better understand how individual subregions differ and how their policies impact economic viability. Attempts to understand subcounty markets would also be useful, as energy and installation pricing varies within counties (i.e. neighborhood, specific house layout) and by installer. Alternative market structures may also exist (e.g. ZIP code clustering). Future attempts should also be made to get a sufficient number of solar PV installer financing options and PPAs to allow them to be modeled in the LCCA.

\section{References}

[1] Barbose G, Darghouth N, LaCommare K, Millstein D, Rand J (2018) Tracking the Sun: Installed Price Trends for Distributed Systems in the United States - 2018 Edition. (Lawrence Berkeley National Lab.(LBNL), Berkeley, CA (United States)). 
[2] EnergySage (2019) How Much Does The Average Solar Panel Installation Cost $n$ the US. Available at https://news.energysage.com/how-much-does-the-average-solarpanel-installation-cost-in-the-u-s/.

[3] Fu R, Margolis RM, Feldman DJ (2018) US Solar Photovoltaic System Cost Benchmark: Q1 2018. (National Renewable Energy Lab.(NREL), Golden, CO (United States)).

[4] EnergySage (2018a) EnergySage's Solar Marketplace Intel Report: H1 2018 H2 2018.

[5] O'Shaughnessy EJ , Margolis RM (2017a) The Value of Transparency in Distributed Solar PV Markets. (National Renewable Energy Lab.(NREL), Golden, CO (United States)).

[6] Kneifel J , O'Rear E (2015) Comparing the energy and economic performance of the NIST NZERTF design across the mixed-humid climate zone. NIST Special Publication 1603.

[7] O'Shaughnessy EJ (2018) The Evolving Market Structure of the US Residential Solar PV Installation Industry, 2000-2016. (National Renewable Energy Lab.(NREL), Golden, CO (United States)).

[8] O'Shaughnessy E (2019) Non-monotonic effects of market concentration on prices for residential solar photovoltaics in the United States. Energy Economics 78:182191.

[9] Marszal AJ , Heiselberg P (2011) Life cycle cost analysis of a multi-storey residential net zero energy building in Denmark. Energy 36(9):5600-5609.

[10] Leckner M, Zmeureanu R (2011) Life cycle cost and energy analysis of a Net Zero Energy House with solar combisystem. Applied Energy 88(1):232-241.

[11] Kannan R, Leong K, Osman R, Ho H, Tso C (2006) Life cycle assessment study of solar PV systems: An example of a $2.7 \mathrm{kWp}$ distributed solar PV system in Singapore. Solar energy 80(5):555-563.

[12] Swift KD (2013) A comparison of the cost and financial returns for solar photovoltaic systems installed by businesses in different locations across the United States. Renewable Energy 57:137-143.

[13] Lang T, Gloerfeld E, Girod B (2015) Don' t just follow the sun-A global assessment of economic performance for residential building photovoltaics. Renewable and Sustainable Energy Reviews 42:932-951.

[14] Farias-Rocha AP, Hassan KMK, Malimata JRR, Sánchez-Cubedo GA, RojasSolórzano LR (2019) Solar photovoltaic policy review and economic analysis for ongrid residential installations in the Philippines. Journal of Cleaner Production 223:45-56.

[15] Kouhestani FM, Byrne J, Johnson D, Spencer L, Hazendonk P, Brown B (2019) Evaluating solar energy technical and economic potential on rooftops in an urban setting: the city of Lethbridge, Canada. International Journal of Energy and Environmental Engineering 10(1):13-32.

[16] Kalke D, Kokkonda K, Kulkarni P (2018) Financial Analysis of Grid-tied Rooftop Solar Photovoltaic System employing Net-Metering. 2018 International Conference on Smart Electric Drives and Power System (ICSEDPS), (IEEE), pp 87-92.

[17] Patel AM, Singal SK (2018) LCC analysis for economic feasibility of rural electrification by hybrid energy systems. Materials Today: Proceedings 5(1):15561562. 
[18] Rodríguez LR, Lissén JMS, Ramos JS, Jara EÁR, Domínguez SÁ (2016) Analysis of the economic feasibility and reduction of a building's energy consumption and emissions when integrating hybrid solar thermal/PV/micro-CHP systems. Applied Energy 165:828-838.

[19] Lee M, Hong T, Koo C, Kim C-J (2018) A break-even analysis and impact analysis of residential solar photovoltaic systems considering state solar incentives. Technological and Economic Development of Economy 24(2):358-382.

[20] Campoccia A, Dusonchet L, Telaretti E, Zizzo G (2009) Comparative analysis of different supporting measures for the production of electrical energy by solar PV and Wind systems: Four representative European cases. Solar Energy 83(3):287-297.

[21] Campoccia A, Dusonchet L, Telaretti E, Zizzo G (2014) An analysis of feed'in tariffs for solar PV in six representative countries of the European Union. Solar Energy 107:530-542.

[22] Dusonchet L, Telaretti E (2015) Comparative economic analysis of support policies for solar PV in the most representative EU countries. Renewable and Sustainable Energy Reviews 42:986-998.

[23] Sow A, Mehrtash M, Rousse DR, Haillot D (2019) Economic analysis of residential solar photovoltaic electricity production in Canada. Sustainable Energy Technologies and Assessments 33:83-94.

[24] Burns JE , Kang J-S (2012) Comparative economic analysis of supporting policies for residential solar PV in the United States: Solar Renewable Energy Credit (SREC) potential. Energy Policy 44:217-225.

[25] Bauner C, Crago CL (2015) Adoption of residential solar power under uncertainty: Implications for renewable energy incentives. Energy Policy 86:27-35.

[26] EnergySage (2018b) EnergySage Solar Photovoltaic Installation Quotation Database - Subset: Washington DC, Mongomery County MD, Prince George's County MD, Fairfax County MD, Arlington County MD. Available at https://www.energysage.com/data/.

[27] O'Shaughnessy E, Margolis R (2017b) Using residential solar pv quote data to analyze the relationship between installer pricing and firm size. (National Renewable Energy Lab.(NREL), Golden, CO (United States)).

[28] Emrath P (2013) The "Right" Rate of Return for Energy Efficiency. (National Association of Home Builders).

[29] Hoen B, Wiser R, Adomatis S, Jackson T, Graff-Zivin J, Thayer M, Klise GT (2015) SELLING INTO THE SUN: PRICE PREMIUM ANALYSIS OF A MULTI-STATE DATASET OF SOLAR HOMES. (Office of Energy Efficiency and Renewable Energy, Solar Energy Technologies Office, U.S. Department of Energy).

[30] System Advisor Model 2017.9.5 (SAM 2017.9.5) (National Renewable Energy Laboratory (Golden, CO). Available at https://sam.nrel.gov/download.

[31] SolSystems (2019) SREC Customer - State Markets (https://www.solsystems.com/srec-customers/state-markets/). Available at

[32] SunPower (2012) SunPower Limited Product and Power Warranty for PV Modules. Available at http://www.diablosolar.com/docs/partners/sunpower-warranty-modulesv2014-8.pdf. 
[33] Solaris Technology Industry Inc. (2019) Power Optimizers: Everything You Need to Know. Available at https://www.solaris-shop.com/blog/power-optimizers-everythingyou-need-to-know/.

[34] HomeAdvisor (2019) How Much Does It Cost To Clean And Maintain Solar Panels? Available at https://www.homeadvisor.com/cost/cleaning-services/solar-panelmaintenance/.

[35] Blanch C (2013) Hidden cost of rooftop solar: Who should pay for maintenance? (Renew Economy). Available at https://reneweconomy.com.au/hidden-cost-ofrooftop-solar-who-should-pay-for-maintenance-99200/.

[36] Trading Economics (2018) United States Inflation Rate. Available at https://tradingeconomics.com/united-states/inflation-cpi.

[37] U.S. Dept. of Energy (2019) Residential and Commercial ITC Factsheets. Available at https://www.energy.gov/eere/solar/downloads/residential-and-commercial-itcfactsheets.

[38] SunPower Corporation (2013) SunPower Module 40-year Useful Life. Available at https://us.sunpower.com/sites/default/files/media-library/white-papers/wp-sunpowermodule-40-year-useful-life.pdf.

[39] Lavappa PD , Kneifel JD (2018) Energy Price Indices and Discount Factors for LifeCycle Cost Analysis-2018. Annual supplement to NIST Handbook 135.

[40] Kneifel J, Webb D, O'Rear E (2016) Energy and Economic Implications of Solar Photovoltaic Performance Degradation.

[41] Electricity Local (2019a) Fairfax Electricty Rates. Available at https://www.electricitylocal.com/states/virginia/fairfax/.

[42] Electricity Local (2019b) Alexandria Electricty Rates. Available at https://www.electricitylocal.com/states/virginia/alexandria/.

[43] US Bureau of Labor and Statistics (2019) Average Energy Prices - Washington DC. Available at https://www.bls.gov/regions/midatlantic/data/averageenergyprices_washingtonde table.htm.

[44] Pepco (2019a) Rate Schedules for Electric Service in Maryland.

[45] Southern Maryland Electric Cooperative (2019) Calculate a Bill. Available at https://www.smeco.coop/account/residential-bill-calculator.

[46] Pepco (2019b) Rate Schedules for Electric Service in the District of Columbia.

[47] Virginia Department of Mines M, and Energy (2019) Net Metering. Available at https://www.dmme.virginia.gov/DE/NetMetering.shtml.

[48] Pepco (2019c) Example Bill. Available at https://www.pepco.com/MyAccount/MyBillUsage/Documents/Updated $\% 20010419 \%$ 20-\%20R.pdf.

[49] Virginia Electric and Power Company (2019) Dominion Energy Tariff.

[50] SolSystems (2019a) Maryland. Available at https://www.solsystems.com/sreccustomers/state-markets/maryland/.

[51] SolSystems (2019b) Washington, D.C. Available at https://www.solsystems.com/srec-customers/state-markets/maryland/.

[52] NC Clean Energy Technology Center (2017) Database of State Incentives for Renewables and Efficiency (DSIRE): Rules, Regulations, and Policies for Energy Efficiency Database.

[53] Siegel JJ , Coxe DG (2002) Stocks for the long run (McGraw-Hill New York), Vol. 3. 


\section{Appendix A: Supplemental Materials}

Table 14. Results of Iterating Base Year for Regression 1

\begin{tabular}{|l|r|r|r|l|l|l|}
\hline $\begin{array}{l}\text { Regression } \\
\text { Variable } \\
\text { Coefficient }\end{array}$ & \multicolumn{2}{|l|}{ 2016 Base Year } & \multicolumn{2}{l|}{ 2017 Base Year } & \multicolumn{2}{l|}{ 2018 Base Year } \\
\cline { 2 - 8 } & Coef. & P>t & \multicolumn{1}{l|}{ Coef. } & P>t & \multicolumn{1}{l|}{ Coef. } & P>t \\
\hline Size & 3.004 & $<0.000$ & 2.604 & $<0.000$ & 2.824 & $<0.000$ \\
\hline Year\#Size & & & & & & \\
\hline 2015 & -0.0607 & 0.340 & 0.339 & $<0.000$ & 0.119 & 0.057 \\
\hline 2016 & N/A & N/A & 0.400 & $<0.000$ & 0.179 & $<0.000$ \\
\hline 2017 & -0.400 & $<0.000$ & N/A & N/A & -0.220 & $<0.000$ \\
\hline 2018 & -0.179 & $<0.000$ & 0.220 & $<0.000$ & N/A & N/A \\
\hline Constant & 1409 & $<0.000$ & 1409 & $<0.000$ & 1409 & $<0.000$ \\
\hline
\end{tabular}

Table 15. Results of Iterating Base Year for Regression 2

\begin{tabular}{|c|c|c|c|c|c|c|c|c|}
\hline \multirow{2}{*}{$\begin{array}{l}\text { Regression } \\
\text { Variable } \\
\text { Coefficient }\end{array}$} & \multicolumn{2}{|c|}{$A C$ as Base County } & \multicolumn{2}{|c|}{$F C$ as Base County } & \multicolumn{2}{|c|}{$M C$ as Base County } & \multicolumn{2}{|c|}{$P G$ as Base County } \\
\hline & Coef. & $\mathbf{P}>\mathbf{t}$ & Coef. & $P>t$ & Coef. & $P>t$ & Coef. & $\mathbf{P}>\mathbf{t}$ \\
\hline \multicolumn{9}{|l|}{ County } \\
\hline DC & -914.4 & 0.343 & -38.3 & 0.959 & 611.9 & 0.599 & 40.1 & 0.961 \\
\hline AC & N/A & $\mathrm{N} / \mathrm{A}$ & 876.1 & 0.385 & 1526 & 0.257 & 954.5 & 0.369 \\
\hline FC & -876.1 & 0.385 & N/A & N/A & 650.2 & 0.588 & 78.4 & 0.928 \\
\hline MC & -1526 & 0.257 & -650.2 & 0.588 & N/A & $\mathrm{N} / \mathrm{A}$ & -571.8 & 0.646 \\
\hline PG & -954.5 & 0.369 & -78.4 & 0.928 & 571.8 & 0.646 & N/A & N/A \\
\hline Tier (Premium) & 2033 & 0.231 & 1397 & 0.114 & 1172 & 0.313 & 605.5 & 0.502 \\
\hline Size & 2.619 & $<0.000$ & 2.651 & $<0.000$ & 2.670 & $<0.000$ & 2.657 & $<0.000$ \\
\hline \multicolumn{9}{|l|}{ County\#Tier } \\
\hline DC\#Premium & -1146 & 0.527 & -511.0 & 0.639 & -285.9 & 0.829 & 280.8 & 0.799 \\
\hline AC\#Premium & $\mathrm{N} / \mathrm{A}$ & $\mathrm{N} / \mathrm{A}$ & 635.2 & 0.74 & 860.2 & 0.676 & 1427 & 0.457 \\
\hline FC\#Premium & -635.2 & 0.740 & N/A & N/A & 225.1 & 0.878 & 791.9 & 0.531 \\
\hline MC\#Premium & -860.3 & 0.676 & -225.1 & 0.878 & N/A & N/A & 566.8 & 0.700 \\
\hline PG\#Premium & -1427 & 0.457 & -791.9 & 0.531 & -566.8 & 0.7 & N/A & N/A \\
\hline \multicolumn{9}{|l|}{ County\#Size } \\
\hline DC & 0.167 & 0.154 & 0.135 & 0.115 & 0.0865 & 0.510 & 0.129 & 0.164 \\
\hline AC & $\mathrm{N} / \mathrm{A}$ & $\mathrm{N} / \mathrm{A}$ & -0.0322 & 0.777 & -0.0805 & 0.594 & -0.0378 & 0.750 \\
\hline FC & 0.0322 & 0.777 & N/A & N/A & -0.0483 & 0.706 & -0.00567 & 0.949 \\
\hline MC & 0.0805 & 0.594 & 0.0483 & 0.706 & N/A & $\mathrm{N} / \mathrm{A}$ & 0.0427 & 0.748 \\
\hline PG & 0.0378 & 0.750 & 0.00567 & 0.949 & -0.0427 & 0.748 & N/A & $\mathrm{N} / \mathrm{A}$ \\
\hline \multicolumn{9}{|l|}{ Tier\#Size } \\
\hline Premium & 0.0894 & 0.596 & 0.153 & 0.076 & 0.138 & 0.272 & 0.190 & 0.035 \\
\hline \multicolumn{9}{|l|}{ County\#Tier\#Size } \\
\hline DC\#Premium & 0.0325 & 0.862 & -0.0310 & 0.796 & -0.0156 & 0.917 & -0.0682 & 0.577 \\
\hline AC\#Premium & N/A & N/A & -0.0635 & 0.737 & -0.0482 & 0.818 & -0.101 & 0.598 \\
\hline FC\#Premium & 0.0635 & 0.737 & N/A & $\mathrm{N} / \mathrm{A}$ & 0.0153 & 0.920 & -0.0372 & 0.765 \\
\hline MC\#Premium & 0.0482 & 0.818 & -0.0153 & 0.920 & N/A & $\mathrm{N} / \mathrm{A}$ & -0.0526 & 0.733 \\
\hline PG\#Premium & 0.101 & 0.598 & 0.0372 & 0.765 & 0.0526 & 0.733 & N/A & N/A \\
\hline Constant & 2533 & 0.002 & 1657 & 0.003 & 1007 & 0.341 & 1578 & 0.017 \\
\hline
\end{tabular}


Table 16. Inputs for System Advisor Model $^{25}$

\begin{tabular}{|l|l|l|l|}
\hline Variable & Input & Variable & Input \\
\hline $\begin{array}{l}\text { Location of TMY3 } \\
\text { Weather File }\end{array}$ & $\begin{array}{l}\text { Dulles International } \\
\text { Airport }\end{array}$ & Modules per String & 1 \\
\hline Sky Diffuse Model & Perez & Strings in Parallel & 28 \\
\hline $\begin{array}{l}\text { Weather File } \\
\text { Irradiance Data }\end{array}$ & DNI and DHI & $\begin{array}{l}\text { Number of } \\
\text { Inverters }\end{array}$ & 1 \\
\hline Module & $\begin{array}{l}\text { SunPower SPR-E19- } \\
\text { 320 }\end{array}$ & Shading and Snow & Omitted \\
\hline $\begin{array}{l}\text { Mounting } \\
\text { Configuration }\end{array}$ & Rack & Losses & $\begin{array}{l}\text { Default for DC } \\
\text { Optimizers }\end{array}$ \\
\hline $\begin{array}{l}\text { Heat Transfer } \\
\text { Dimensions }\end{array}$ & Module Dimensions & Lifetime & $\begin{array}{l}0.5 \% / \text { year } \\
\text { degradation rate }\end{array}$ \\
\hline $\begin{array}{l}\text { Inverter } \\
\text { 27 }\end{array}$ & $\begin{array}{l}\text { SolarEdge } \\
\text { Technologies SE9K } \\
\text { 208V }\end{array}$ & $\begin{array}{l}\text { Angle of } \\
\text { Inclination } 2013]\end{array}$ & $\begin{array}{l}18.4 \% \text { based on } \\
\text { NZERTF }\end{array}$ \\
\hline
\end{tabular}

${ }^{25}$ Any variable not listed here is either kept as default or not used, including all financial variables

${ }^{26}$ Also determines latitude for solar irradiance calculation

${ }^{27}$ Optimizer is assumed to be attached to the panel and is not explicitly modeled by SAM

${ }^{28} 208$ Voltage is rare in new construction; however, the grid voltage has minimal impact on the PV generation, and it is assumed that the inverter would be scaled to system size. Therefore, the listed inverter is used. 